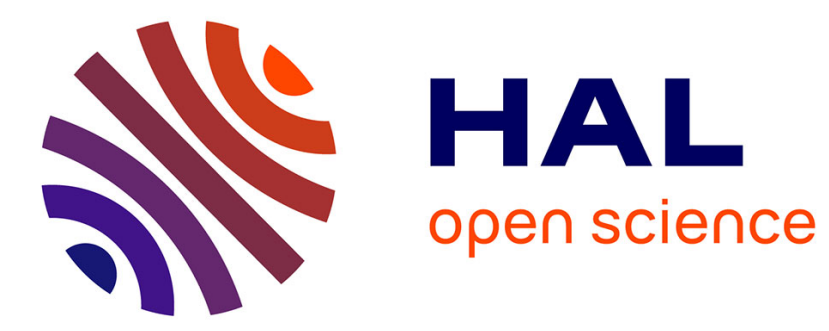

\title{
Northward growth of the Qimen Tagh Range: A new model accounting for the Late Neogene strike-slip deformation of the SW Qaidam Basin
}

Feng Cheng, Marc Jolivet, Suotang Fu, Qiquan Zhang, Shuwei Guan, Xiangjiang Yu, Zhaojie Guo

\section{To cite this version:}

Feng Cheng, Marc Jolivet, Suotang Fu, Qiquan Zhang, Shuwei Guan, et al.. Northward growth of the Qimen Tagh Range: A new model accounting for the Late Neogene strike-slip deformation of the SW Qaidam Basin. Tectonophysics, 2014, 632, pp.32-47. 10.1016/j.tecto.2014.05.034 . insu-01065836

\section{HAL Id: insu-01065836 \\ https://hal-insu.archives-ouvertes.fr/insu-01065836}

Submitted on 18 Sep 2014

HAL is a multi-disciplinary open access archive for the deposit and dissemination of scientific research documents, whether they are published or not. The documents may come from teaching and research institutions in France or abroad, or from public or private research centers.
L'archive ouverte pluridisciplinaire HAL, est destinée au dépôt et à la diffusion de documents scientifiques de niveau recherche, publiés ou non, émanant des établissements d'enseignement et de recherche français ou étrangers, des laboratoires publics ou privés. 


\section{Northward growth of the Qimen Tagh Range: a new model accounting for the}

\section{Late Neogene strike-slip deformation of the SW Qaidam Basin}

Feng Cheng ${ }^{\mathrm{a}}$, Marc Jolivet ${ }^{\mathrm{b}}$, Suotang Fu ${ }^{\mathrm{c}}$, Qiquan Zhang ${ }^{\mathrm{c}}$, Shuwei Guan ${ }^{\mathrm{d}}$, Xiangjiang $\mathrm{Yu}{ }^{\mathrm{a}}$, Zhaojie Guo ${ }^{\text {a, * }}$

${ }^{a}$ Key Laboratory of Orogenic Belts and Crustal Evolution, Ministry of Education, School of Earth and Space Sciences, Peking University, Beijing, 100871, China

${ }^{b}$ Laboratoire Géosciences Rennes, CNRS-UMR6118, Université Rennes 1 - Observatoire des

Sciences de L'Univers de Rennes, Rennes, France

${ }^{c}$ Qinghai Oilfield Company, PetroChina, Dunhuang, Gansu, 736202, China

${ }^{d}$ Research Institute of Petroleum Exploration and Development, PetroChina, Beijing, 100083,

China

${ }^{*}$ Corresponding author. Tel.: + 86-10-62753545; fax: + 86-10-62758610. E-mail address: zjguo@pku.edu.cn 


\section{Abstract}

Situated along the western termination of the Eastern Kunlun Mountains, the Qimen Tagh Range represents a key area to understand the Cenozoic basin-range interactions between the northeastern Tibetan Plateau and the Qaidam Basin. Within that region, several huge bow-like fault systems such as the Kunbei and Qimen Tagh fault systems accommodate the transpressive deformation but their kinematic evolution is still highly debated. Newly acquired seismic profiles and isopach maps of the Late Eocene sediments strongly suggest that the Kunbei fault system (consisting of the Kunbei, Arlar and Hongliuquan faults) in the southwestern Qadaim Basin was initially a left-lateral strike-slip fault system rather than a thrusting system. Growth strata indicate an Early Miocene onset age for this strike-slip deformation. However, earthquakes focal mechanisms show that the present-day tectonic pattern of this fault system is dominated by NE-SW transpression. As for the Qimen Tagh fault system, numerous linear geomorphic features and fault scarps indicate that it was again a strike-slip fault system. Deformed sediments within the Adatan Valley prove that strike-slip motion prevailed during the Pleistocene, yet the present day deformation is marked by NE-SW transpression. Collectively, the Kunbei and Qimen Tagh fault systems were initially left-lateral strike-slip fault systems that formed during Early Miocene and Pleistocene respectively. Colligating with these southward younging left-lateral strike-slip faulting ages and the fact that these convex-northward structures converge to the center segment of active Kunlun Fault in the east, we thus considered the Kunbei and Qimen Tagh fault systems as former western segments of the Kunlun Fault once located further south in the present-day location of that fault. These faults gradually migrated northward since the Early Miocene while their kinematics changed from left-lateral strike-slip motion to NE-SW transpression. 
Keywords: Cenozoic tectonics, North Tibet, Kunlun Fault, Qimen Tagh Range, southwestern Qaidam Basin. 


\section{Introduction}

The Eastern Kunlun Mountains and adjacent Qaidam Basin present one of the strongest topographic gradients in Eurasia, similar to that of the Longmen Shan Range in East Tibet (Fig. 1). Within that region, the left-lateral strike-slip Kunlun Fault Zone represents one of the key tectonic features controlling the active deformation along the northern margin of the Tibetan Plateau (e.g. Avouac and Tapponnier, 1993; Meyer et al., 1998; Jolivet et al., 2001; Tapponnier et al., 2001; Xia et al., 2001 ;Yin et al., 2007). Most of the previous studies that dealt with the Tertiary deformation in the East Kunlun ranges focused on the central and eastern segment of the Kunlun Fault (Kirby et al., 2007; Harkins and Kirby, 2008) where the deformation is mostly localized along the major, unique strike-slip fault zone. However, only a limited number of studies describe the more structurally complex western termination of the Kunlun Fault system (Jolivet et al., 2001, 2003).

Although the Cenozoic tectonic evolution of North Tibet has been largely studied, the relationship between the Qaidam Basin and the East Kunlun Range, as well as the tectonic pattern of the Kunlun Fault itself, remains controversial. For example, several contradicting models have been proposed to describe the tectonic structure of the southern edge of the Qaidam Basin: a crustal-scale south-dipping thrust system (Burchfiel et al., 1989); a large transpressional system including the left-lateral strike - slip Kunlun Fault to the south and a north - directed thrust system along the northern flank of the Eastern Kunlun Mountains (Meyer et al., 1998; Tapponnier et al., 2001; Jolivet et al., 2003); or a series of north - dipping thrusts carrying the Qaidam Basin southward onto the Qimen Tagh Range (Yin et al., 2007; Shi et al., 2009; Wang et al., 2011). Within most of those models, the large amount of Cenozoic strike-slip motion along the Kunlun 
Fault (Fu and Awata, 2007) is generally considered as secondary in controlling the overall structural setting of the SW Qaidam Basin and East Kunlun Range. However, if the boundary fault between the Qaidam Basin and the East Kunlun Range was indeed accommodating a large amount of lateral displacement, the southern Qaidam Basin should be largely decoupled from the Tibetan Plateau to the south and should not be affected by major N-S compression and shortening since the initiation of the strike-slip Kunlun Fault. Nonetheless, the Qimen Tagh Range, bordering the SW Qaidam Basin to the south forms a convex-northward bow-like tectonic prism clearly accommodating shortening along the southern margin of the basin while strike-slip motion occurs along the Kunlun Fault to the south.

This paper aims to re-evaluate the tectonic pattern along the western portion of the Kunlun Fault and to decipher the Late Cenozoic interaction between the East Kunlun Range and the SW Qaidam Basin in the Qimen Tagh Range. This work is based on new field observation and data, interpretation of newly acquired seismic reflection profiles within the SW Qaidam Basin, remote sensing images, and earthquake focal mechanisms and epicenters distribution. Based on those data we propose that the Late Neogene northward growth of the convex-northward structures in the Qimen Tagh Range and SW Qaidam Basin is driven by left-lateral strike-slip motion along the Kunlun Fault. While migrating northward, the western segment of the Kunlun Fault gradually rotates through time. This northward rotation induces a progressive change from left-lateral strike-slip to NE-SW compressional motion. Continuous activity along the Kunlun Fault finally initiates a new strike-slip segment. 


\section{Regional Geology}

\subsection{Eastern Kunlun Mountains}

The Eastern Kunlun Mountains, with an average altitude of $\sim 4500 \mathrm{~m}$, separates the relatively low-relief Qaidam Basin to the north from the Hoh Xil Basin to the south. The Kunlun Fault Zone itself represents a major tectonic boundary between the Bayan Har-Songpan Garze terrane and the Kunlun-Qaidam basement (e.g. Meyer et al., 1996). The fault extends about $1600 \mathrm{~km}$ along-strike, initiating on the eastern margin of the Tibetan Plateau (Kirby et al., 2007; Lin and Guo, 2008) and ending in a splay structure with several curved faults in the west (Xu et al., 2002; Fu and Awata, 2007) (Fig. 1). Intense seismicity attests of the activity of this left-lateral strike-slip fault system (e.g., $M_{w} 7.8$ Kunlunshan earthquake in 2001(Lin et al., 2002; Xu et al., 2002); $M_{w} 7.6$ Manyi earthquake in 1997 (Peltzer et al., 1999); $M_{w} 7.5$ Manyi earthquake in 1973 (Velasco et al., 2000); $M_{w} 7.5$ Tuosu Lake earthquake in 1937 (Guo et al., 2007); $M_{s}$ 7.0 Alake Lake earthquake in 1963(Guo et al., 2007)). Both GPS and geological data suggest that the central segment of the Kunlun Fault has a uniform slip rate of ca.10 mm/yr (Kidd and Molnar, 1988; Van Der Woerd et al., 1998; Wang et al., 2001; Zhang et al., 2004; Fu et al., 2005; Kirby et al., 2007). This rate decreases to $\sim 5 \mathrm{~mm} / \mathrm{yr}$ along its eastern segment and finally dies out toward the eastern fault tip (Kirby et al., 2007; Harkins and Kirby, 2008). The total displacement along the fault since its initiation is approximately $100 \pm 20 \mathrm{~km}$ according to the largest cumulative offset of basement rocks along the tectonic lineament (Fu and Awata, 2007).

The Cenozoic deformation and exhumation history of the Eastern Kunlun Mountains is complex and still largely debated. For instance, the onset age of the Cenozoic cooling event in this 
area range from 35 to 10 Ma depending on the authors (Mock et al., 1999; Jolivet et al., 2001; Wang et al., 2004a; Liu et al., 2005; Yuan et al., 2006; Clark et al., 2010; Duvall et al., 2013). However, the onset age of left-lateral strike-slip motion along the Kunlun Fault has been estimated to be 15 Ma or earlier (Jolivet et al., 2003). Similarly, based on the growth strata records in the seismic profiles across the SW Qaidam Basin, Yin et al. (2008) asserted that the Cenozoic deformation across the Qimen Tagh Range and in the SW Qaidam Basin, directly related to the tectonic development of the Kunlun Fault Zone, initiated during or after Late Oligocene to Early Miocene times.

\subsection{SW Qaidam Basin and Kumukol Basin}

The $\sim 3500 \mathrm{~m}$ high (on average), low relief triangular Qaidam Basin is bounded by the Altyn Tagh Range to the northwest, the Eastern Kunlun Mountains to the south, and the Qilian Shan to the northeast (Fig. 1). Recent geological cross sections within the Qaidam Basin, mostly based on seismic profiles and drill cores data, demonstrate that the upper Cretaceous and Tertiary sediments rest unconformably on the Jurassic to Cretaceous strata. This unconformity indicates that some deformation already took place within the basin during the Cretaceous (Xia et al., 2001; Fang et al., 2007). The Cenozoic sequences mainly consist of a series of continental clastic deposits (Fig. 2).

The successive depocenters were consistently located along the long axis of the basin and gradually migrated eastward since the Eocene (Balley, 1986; Song and Wang, 1993; Qiu, 2002; Xia et al., 2001; Sun et al., 2005; Yin et al., 2008).

The chronology of the Cenozoic stratigraphic units has been precisely defined (Fig. 2) mostly using magnetostratigraphy, but also based on palynology and paleontology studies within the entire basin (QBGMR, 1991; Yang et al., 1992; Deng et al., 2004a, 2004b; Sun et al., 2005; Song 
et al., 2006; Zhang et al., 2006; Fang et al., 2007; Sun et al., 2007; Wang et al., 2007; Lu and

Xiong, 2009; Ke et al., 2013). The series include: (1) the Lulehe Formation, $\mathrm{E}_{1+2} l,>53.5-43.8 \mathrm{Ma}$

(Yang et al., 1992; Song et al., 2006; Zhang, 2006; Ke et al., 2013); (2) the lower Xiaganchaigou

Formation, $\mathrm{E}_{3}{ }^{1} \mathrm{xg}, 43.8$ - 37.8 Ma (Song et al., 2006; Zhang, 2006; Sun et al., 2007; Pei et al.,

2009); (3) the upper Xiaganchaigou Formation, $\mathrm{E}_{3}^{2} \mathrm{xg}, 37.8$ - $35.5 \mathrm{Ma}$ (Sun et al., 2005; Sun et al.,

2007; Pei et al., 2009); (4) the Shangganchaigou Formation, $\mathrm{N}_{1}$ sg, 35.5 - $22.0 \mathrm{Ma}$ (Sun et al., 2005;

Lu and Xiong, 2009); (5) the lower Youshashan Formation, $\mathrm{N}_{2}{ }^{1} x y, 22.0$ - $15.3 \mathrm{Ma}$ (Fang et al.,

2007; Lu and Xiong, 2009); (6) the upper Youshashan Formation, $\mathrm{N}_{2}^{2} s y, 15.3$ - 8.1 Ma (Fang et al., 2007); (7) the Shizigou Formation, $\mathrm{N}_{2}{ }^{3} s, 8.1-2.5 \mathrm{Ma}$ (Fang et al., 2007); and finally, (8) the

Quaternary sediments, including the Qigequan Formation $\left(\mathrm{Q}_{1} q\right)$ and the Dabuxun - Yanqiao

Formation, 2.5 - 0 Ma (Fang et al., 2007; Yin et al., 2008). The boundaries between these

formations have been labeled $T_{R}, T_{5}, T_{4}, T_{3}, T_{2}, T_{2}, T_{1}$ and $T_{0}$ (from bottom to top) by petroleum geologists and will be used as it below (Fig. 2).

The Kumukol Basin (Figs. 1 and 2), with an average elevation of $\sim 4000 \mathrm{~m}$, is located between the Qimen Tagh Range to the north and the western branches of the Eastern Kunlun Range to the south. Remote sensing image and field evidence indicate that the northern part of the Kumukol Basin is bordered by an active fault which controls the distribution of the present drainage system (IGSSP, 2003). The basin contains an Eocene to Pliocene sequence which has been deformed into a NW-SE oriented syncline (Meng and Fang, 2008). Based on fossils and stratigraphic correlation (Zhang et al., 1996), these Tertiary sequences can be divided into four units (from bottom to top) (Meng and Fang, 2008): the Huatiaoshan Formation (Eocene to Oligocene), the Hongshiliang Formation (Early Miocene), the Fengchenkou Formation (Middle Miocene), and the Jiantuliang 
Formation (Pliocene to Pleistocene). The Eocene to Oligocene series in the Kumukol Basin are dominated by lacustrine deposits (IGSSP, 2003) displaying similar facies and depositional environments as the Eocene to Oligocene deposits in the SW Qaidam Basin and Hoh Xil Basin. This similarity of the deposits within the three basins suggests that they were largely connected during the Paleogene (Yin et al., 2008). 


\section{Active tectonic pattern in the western segment of the East Kunlun Range}

The distribution and focal mechanisms of earthquakes reflect the occurrence and kinematics of active faults and allow describing the active tectonic pattern of the study area (e.g. Taylor and Yin, 2009; Jolivet et al., 2013). We analyzed the parameters of all earthquakes in an area between $89^{\circ} \mathrm{E}$ to $98^{\circ} \mathrm{E}$ and $35^{\circ} \mathrm{N}$ to $39^{\circ} \mathrm{N}$, for which precisely determined hypocenter depths and focal mechanisms are available. The epicenters and depth - frequency distribution of seismicity used in this study are issued from the China Earthquakes Network Center (CENC). Only events with magnitude $M>3$ that occurred between 1970 and 2011 have been considered (Fig. 3). Focal mechanisms were obtained from the U.S. Geological Survey and the Global Centroid Moment Tensor Project. The depth - frequency distribution of seismicity is presented along two profiles, A - A' (Fig. 4a) and B - B' (Fig. 4b) (See Fig. 3 for the location of the profiles). The epicenters of earthquakes situated between $89^{\circ} \mathrm{E}$ to $92^{\circ} \mathrm{E}$ and $35^{\circ} \mathrm{N}$ to $39^{\circ} \mathrm{N}$ are projected on profile A-A'; Those of the earthquakes situated between $90^{\circ} \mathrm{E}$ to $98^{\circ} \mathrm{E}$ and $35^{\circ} \mathrm{N}$ to $37^{\circ} \mathrm{N}$ are projected on profile B-B' .

Earthquakes magnitude ranges from $M=3$ (the selected cut-off value) to $M=7$. Strong tectonic activities (mean $M$ between 5 and 6) are recorded along the Eastern Kunlun Mountains, on the southern edge of the Qaidam Basin. However, diffuse seismicity (mean $M$ between 4 and 5) also occurs inside the basin (Fig. 3 and 4). Surprisingly, the Qimen Tagh Range displays a relative lack of seismicity. Within the Eastern Kunlun Mountains, the distribution and focal mechanisms of the earthquakes are coherent with left-lateral, transpressive strike-slip movement on the Kunlun Fault. The existing few transtensive focal mechanisms can be explained by the occurrence of 
extensional relay-zones along the main Kunlun Fault (Jolivet et al., 2003). The focal mechanisms available inside the Qimen Tagh Range and the SW Qaidam Basin all correspond to reverse faults activity indicative of a general compressive stress field with no or extremely limited strike-slip motion.

The depth-frequency distribution of the earthquakes indicates that both in the Eastern Kunlun Mountains and in the Qaidam Basin, seismicity affects the upper 30 to $35 \mathrm{~km}$ of the crust (that is thought to be at least $50 \mathrm{~km}$ thick in that region (e.g. Jolivet et al., 2003; Zhang et al., 2011)) with most events occurring in the upper 10 to $15 \mathrm{~km}$. This distribution pattern is similar to the depth-frequency distribution of seismicity over the entire Tibetan Plateau (Taylor and Yin, 2009), with exceptions where earthquakes might have occurred within the lower crust or upper lithospheric mantle (Chu et al., 2009). The observed seismicity is thus mostly indicative of the deformation of the upper to middle crust and can be reasonably compared to the fault pattern observed on the surface. 


\section{Splay Fault System of the Kunlun Fault Zone}

Different from the typical horse-tail structure, the western segment of the Kunlun Fault develops several asymmetric northward curved structures topographically characterized by a series of ridges and valleys (Fig. 1). These elongated linear geomorphic landforms are similar to those of the central segment of the Kunlun Fault, such as the Xidatan and Dongdatan valleys (Xu et al., 2002), and indicate the occurrence of left-lateral strike-slip faulting. Meanwhile, the valleys are largely filled with Cenozoic deposits that recorded the history of the strike-slip faulting and especially its onset time. In this study, taking the Qimen Tagh Range as an example, we aim at clarifying the tectonic pattern of the western segment of the Kunlun Fault through time.

\subsection{Strike-slip faulting in the Qimen Tagh Range}

The Qimen Tagh Range, located in the western part of the Eastern Kunlun Mountains, is over $\sim 4500 \mathrm{~m}$ high on average and marks the boundary between the Kumukol Basin to the south and the Qaidam Basin to the north (Fig. 1). The range has a general WNW-ESE elongated shape. To the NW, it bends sharply to a southwestward trend sub-parallel to the Altyn Tagh Range that lies directly to the north. To the SE, the Qimen Tagh Range converges with the Eastern Kunlun Mountains (Fig. 1 and 5). It is separated into two parallel NW-SE oriented sub-ranges by the Adatan Valley (Fig. 2).

To the north, the sharp contact between the Qaidam Basin and the Qimen Tagh Range has been interpreted as evidence for active north-directed thrusting (e.g., Meyer et al., 1998; Jolivet et al., 2003), whereas field examination suggests that this is a steeply north-dipping unconformity between bedrock in the south and north-dipping Cenozoic strata in the north (Yin et al., 2007). 
Detailed analysis of both SRTM digital elevation models (DEM) and Landsat 5 satellite images across the Qimen Tagh Range reveals abundant tectonic lineaments (Fig. 5). The extensive Qimen Tagh fault system consists of two major, sub-parallel tectonic lineaments: the Middle Qimen Tagh Fault (MQF) and the South Qimen Tagh Fault (SQF) (Fig. 5).

The MQF affects the northern edge of the Adatan Valley. Based on field measurements and on previous studies (Wang et al., 2007), the MQF dips about $55^{\circ}$ to the south. The strike of the $\mathrm{MQF}$ changes from ENE in the western part of the range to WNW in the eastern part. The western segment shows a reverse motion associated to a slight left-lateral strike-slip component. Some of the scarps and branched faults are arranged in echelons (Fig. 6). In the eastern part of the MQF the main active fault is obliterated by Quaternary deposits. However, some linear structures are visible on the eastern end of the MQF and in the convergence zone with the Kunlun Fault system (Figs. 5 and 7). This however poorly exposed tectonic pattern suggests a very probable connection between the Qimen Tagh Fault system in the west and the Kunlun Fault system in the east.

The SQF separates the southern sub-range of the Qimen Tagh Range from the Kumukol Basin to the south (Fig. 5). The fault zone is marked by a series of distinctive fault scarps and structural lineaments which are inferred to be reverse faults striking approximately NE120 (Fig. 5). Furthermore, several evidences of recent activity such as river offsets and alluvial fan displacements indicate a left-lateral reverse movement on the fault.

Although the offset channels and geomorphic surfaces indicate a recent, probably still active general left-lateral shearing within the range, the focal mechanism solution mentioned above suggest that this recent left-lateral strike-slip faulting is relatively slight compared to the NE-SW compressive component. 


\subsection{Pleistocene series within the Adatan valley}

Fieldwork in the Adatan Valley was conducted to determine the timing of the strike-slip faulting in the south Qimen Tagh sub-range. Detailed analysis of the Cenozoic syntectonic deposits was conducted to provide a better understanding of the deformation in the Qimen Tagh Range (Fig. 8).

The morphology of the Adatan Valley is marked by a strong topographic relief between the valley and the mountains (Fig. 8a). Within the two sub-ranges, the series are mainly composed of Precambrian basement, Paleozoic metasediments and Paleozoic and Mesozoic igneous rocks. The Cenozoic series exposed within the Adatan Valley was assigned a Pleistocene age based on previous geology mapping and regional stratigraphic correlation (IGSSP, 2003; IGSQP, 2004; Wang et al., 2004b; Wang et al., 2007; Fu et al., 2008).

The deposits are deformed into several anticlines cut by modern rivers within the valley (Figs. 8a and 9). Along the northern edge of the valley, the Cenozoic series overlap northward on the Ordovician basement and are dominated by a sequence of conglomerates and sandstones. Along the southern edge of the valley, the Cenozoic series are deformed and uncomformably covered by Holocene tillites and alluvial sediments. As in the north, these deposits are composed of coarse-grained conglomerates and sandstones in alluvial fans facies. The petrological composition of the conglomerates corresponds to the whole range of basement rocks exposed in the Qimen Tagh Range, including igneous, metamorphic rocks and marine limestones. Poor sphericity and poor sorting of the grains indicate very proximal deposits. The grain size generally increases upward (Fig. 8b). Similarly to the Quaternary sedimentary within the Xidatan Valley further east (Xu et al., 2002) that record the present active feature of the Kunlun Fault, the Pleistocene 
sequences exposed in the Adatan Valley record the topographic growth of both the north and south Qimen Tagh sub-ranges. They indicate a Pleistocene age for the onset of strike-slip faulting in the Qimen Tagh Range.

As a consequence, the linear geomorphic features, occurrence of faults scarps in the Qimen Tagh Range as well as the deformed Pleistocene deposits in the Adatan Valley indicate that the reverse strike-slip deformation in the region has been active since the Pleistocene. 


\section{Strike-slip faulting in the SW Qaidam Basin}

In order to decipher the Cenozoic strike-slip faulting pattern in the SW Qaidam Basin, we choose the isopach map of the upper Xiaganchaigou Fm. $\left(\mathrm{E}_{3}{ }^{2} \mathrm{xg}\right)$ as an example to analyze the impact of fault motion on the sediment distribution within the basin (Fig. 10). Data were obtained from the Qinghai Oilfield Company (China) who recently compiled information from thousands of drill holes and a dense network of seismic profiles.

The Kunbei fault system was composed of three major WNW trending faults, including the Kunbei Fault, the Arlar Fault and the Hongliuquan Fault. As reported on the isopach map based on seismic data, these three faults controls the general tectonic pattern of the SW Qaidam Basin. The Kunbei Fault and Arlar Fault have been previously interpreted as reverse faults active since the Paleogene (Wang et al., 2010). However, the three major faults mentioned above are arranged into a left-lateral right-step en-échelon pattern (Fig. 10), that does not correspond to the usual imbricated pattern of purely compressive thrust systems such as, for example, in the Appalachian thrust belt (Macedo and Marshak, 1999; Thomas, 2001) or in the Zagros fold and thrust belt (McQuarrie, 2004; Sepehr and Cosgrove, 2004). Meanwhile, the isopach lines of the Late Eocene Upper Xiaganchaigou Fm. are obviously offset across the faults reflecting a left-lateral strike-slip movement along these three faults. According to the well-expressed offset of the 400 meters isopach line, the left-lateral displacement of the Honglingquan Fault, the Arlar Fault and the Kunbei Fault increases from a few kilometers to tens of kilometers (Fig. 10). Therefore, the variations in thickness of the Late Eocene series across these three faults, as well as the en-échelon pattern of the faults, clearly demonstrates the occurrence of left-lateral strike - slip faulting in the 
SW Qaidam Basin after the Late Eocene.

To further explore the tectonic pattern of the SW Qadaim Basin and the timing of faulting, three seismic reflection profiles (C-C', D-D', E-E') recently acquired by the Qinghai Oilfield Company have been selected. These three NE-trending seismic lines extend from the northern front of the Qimen Tagh Range towards the center of the SW Qaidam Basin (See location on Figs. 2 and 10).

\section{Seismic Section C-C'}

The seismic section C-C' situated in the central part of the SW Qaidam Basin, intersects the Arlar Fault (Fig. 10 and 11). On that section the Arlar Fault is a south dipping high angle fault associated to a few branched faults. The Mesozoic series are not preserved on both sides of the Arlar Fault where only Cenozoic deposits can be identified. Although the strata on each side of the fault consist in the same Cenozoic series, the thickness of each formation is quite different showing obvious stratigraphic throw. This major stratigraphic throw corresponds to the offset observed in the isopach lines of the Late Eocene Upper Xiaganchaigou Fm. on both side of the Arlar Fault (Fig. 10). Combined together, these two sets of data demonstrate a left-lateral reverse motion along the Arlar Fault during the Tertiary.

The thickness of the strata younger than Neogene Xiayoushashan Fm. $\left(\mathrm{N}_{2}{ }^{1} \mathrm{xy}\right)$ decreases towards the Arlar Fault and growth strata develop on both sides of the fault. Based on these features, previous studies interpreted the Arlar Fault as a purely reverse fault that accommodated rapid uplift in the Eastern Kunlun Mountains since the Late Oligocene - Early Miocene (Song and Wang, 1993; Yin et al., 2007; Wang et al., 2010). Since it is very difficult to identify strike-slip faults on seismic profiles (Durand-Riard et al., 2012), these studies did not take into consideration 
the strike-slip component along the major faults within the SW Qaidam Basin. Growth strata are generally used to reveal the initiation time of a reverse fault (e.g. Suppe et al., 1992; Vergés et al., 2002), but strike-slip motion may also induce vertical offset of strata, such as in positive flower structure (e.g. Christophoul et al., 2002). Such motion can also generate growth strata which will then provide an accurate initiation time for the strike-slip faulting (e.g. Hinsch et al., 2005). Consequently, the growth strata associated to the positive flower structure in seismic profile C-C' presented above, as well as the northward thinning of the Early Miocene and younger series in the footwall of the Arlar Fault date the onset time of left-lateral strike-slip faulting along that fault (Fig. 10 and 11).

\section{Seismic Section D-D'}

The tectonic pattern of section D-D' is characterized by several high angle faults defining a block-like structure (Fig. 12). The major faults are the Arlar Fault and the Hongliuquan Fault. The sediments within the section are Mesozoic to Cenozoic in age. The cover sequence in the hanging wall of the Arlar Fault is composed of Cenozoic sediments whereas the footwall is dominated by Late Mesozoic, Paleogene and Early Neogene deposits. The Mesozoic sediments are relatively thick within the footwall where the Tertiary series are also obviously thicker than that of the hanging wall. The basement and Cenozoic strata on both sides of the Arlar Fault display obvious stratigraphic throw. Further to the north, the Early to Middle Cenozoic and Late Mesozoic strata are cut by the north dipping high angle Hongliuquan Fault. In the hangingwall of the Hongliuquan Fault, the pre-Early Miocene strata were deformed in an anticline later cut and sealed by the Early Miocene sediments clearly indicating Early Miocene motion of this fault. Like in profile C-C', the thickness of the Cenozoic units is constant within each tectonic compartment but varies sharply 
between two adjacent blocks. Combined with the offset isopach lines of the Late Eocene deposits

(Fig. 10), this pattern can also be explained by lateral movements along the faults during the

Tertiary. Again like in seismic profile C-C', the occurrence of growth strata initiating in the Early

Miocene series north of the Arlar and Hongliuquan faults implies that left-lateral strike-slip

deformation initiated during the Early Miocene in the SW Qaidam Basin.

\section{Seismic Section E-E}

Seismic section E-E' is located about $20 \mathrm{~km}$ east of seismic section C-C' and again runs from the northern front of the Qimen Tagh Range to the western part of the central Qaidam Basin (Figs. 10 and 13). As in section D-D', the tectonic pattern is characterized by several high angle faults but the cover-sequence only consists in Cenozoic strata. To the south, the activity along the Kunbei Fault is marked in the hanging wall by the erosion of the Late Eocene and younger strata and probably by the non-deposition of some of the upper Tertiary and Quaternary series. This erosion also affects the footwall of the Kunbei Fault, though the Early Tertiary series are better preserved with some Late Eocene sediments still present. Like in section C-C' and D-D', the thickness of the Early Tertiary series vary across the fault showing obvious stratigraphic throw. To the north, the XIII fault dips to the north and cuts the Early to Middle Cenozoic sequence, while the large stratigraphic throw on both sides of the fault decreases from basement to Quaternary series. Like in the previous sections, the thickness of the Paleocene to Eocene strata varies sharply from both sides of the Kunbei and XIII faults, again attesting of lateral movements on those structures during the Tertiary. Furthermore, the thickness of the strata younger than the Xiayoushashan Fm. $\left(\mathrm{N}_{2}{ }^{1} \mathrm{xy}\right)$ within the footwall of the Kunbei and XIII faults decreases towards the faults. Growth strata are again initiating in the footwall of both faults during Early Miocene 
times dating again the onset of deformation in that region.

From what has been discussed above, we conclude that the tectonic attribute of the Kunbei Fault during the Early Miocene is featured by a left-lateral transpressive system mainly composed of the Kunbei Fault, the Arlar Fault and the Hongliuquan Fault. Among these faults, the Kunbei and Arlar faults are the two major boundary faults separating the Cenozoic series within the SW Qaidam Basin from the Kunlun basement to the south. 


\section{Discussion}

\subsection{Available models for the Cenozoic evolution of the SW Qaidam Basin.}

In the past decades, several models have been proposed to explain the Cenozoic tectonic and sedimentary evolution of the Qaidam Basin. Most of those concentrated on the tectonic pattern displayed in the Qimen Tagh Range and SW Qaidam Basin, and simply defined the tectonic pattern between the Eastern Kunlun Mountains and the Qaidam Basin through a northward thrusting or southward thrusting model.

The northward thrusting model prevailed in the last two decades, explaining the subsidence of the Qaidam Basin as a result of the basinward propagation of successive thrust sheets along the southern edge of the basin. Burchfiel et al. (1989) proposed that the southern edge of the Qaidam Basin is limited by a south-dipping thrust fault. However, field observation revealed that the contact between the Eastern Kunlun Mountains and the Qaidam Basin is defined by gentle north-dipping Pliocene strata overlapping north-dipping Carboniferous beds (Yin et al., 2007). Based on a synthesis of focal mechanisms and focal-depth distribution combined with geological features, Chen et al. (1999) again speculated the existence of this south-dipping North Kunlun thrust fault along the northern margin of the East Kunlun belt. However, their data projected on the single cross section were collected along the over $1000 \mathrm{~km}$ long Eastern Kunlun Mountains and Yin et al. (2007) showed that it was not possible to differentiate between the two possible fault planes solutions ( $\mathrm{N}$ dipping or $\mathrm{S}$ dipping). In addition, many authors indicated that northward basement thrusting across the Eastern Kunlun Mountains was associated to the northward propagation of a crustal-scale accretionary wedge initiating around ca. 30-20 Ma. (Meyer et al., 
1998; Mock et al., 1999; Jolivet et al., 2001; Tapponnier et al., 2001; Jolivet et al., 2003; Wang et al., 2006). These ideas suggest that the Eastern Kunlun Mountains consists in a large transpressional system limited to the south by the left-lateral strike-slip Kunlun Fault and to the north by a series of south-verging basement thrusts affecting the southern edge of the Qaidam Basin. Yet, the observed thickness pattern of the Cenozoic strata across the Qaidam Basin (Yin et al., 2008) seems poorly compatible with a major south-dipping range-bounding thrust along the northern margin of the Eastern Kunlun Mountains. All the individual Cenozoic units in the basin consistently thicken from the margins towards the center of the basin (Bally, 1986; Huang et al., 1996; Sobel et al., 2003; Wang et al., 2006; Yin et al., 2007, 2008). This isopach pattern contradicts the classic tectonically subsiding foreland-basin model that requires the maximum sediment thickness to be localized near the bounding thrust system (Jordan, 1981).

The southward thrusting model has drawn much attention in recent years (Yin et al., 2007; Shi et al., 2009; Wang et al., 2011). Yin and Harrison (2000) suggested that two major thrusts, the Qimen Tagh Thrust and the North Kunlun Thrust mark the southern boundary of the Qaidam Basin. Using seismic profiles within the Qaidam Basin and field observations, Yin et al. (2007) then proposed that the low altitude Qaidam Basin has been thrust onto the Eastern Kunlun Mountains along major north dipping Cenozoic thrusts. This model was later expanded by Wang et al., (2011) based on a high-resolution deep seismic reflection profile across this area. This model indicates that the Eastern Kunlun Mountains should not thrust northward onto the Qaidam Basin and that the initiation of compressive deformation along the southern margin of the Qaidam Basin is much younger than along the northern margin of basin. However, this model does not take any strike-slip component in the Qimen Tagh Range and SW Qaidam Basin into account. In 
addition, the convex-northward bow-like tectonic structures in the Qimen Tagh Range are not consistent with southward thrusting of the basin onto the range. Such a deformation pattern would rather generate a southward inflexion of the structures.

Other tectonic models have been proposed aside from the two main ones described above. Xia et al. (2001) proposed that the Qaidam Basin experienced a two stages evolution: an initial extension phase during the Early Tertiary was followed by a compressive phase leading to basin inversion. However, few seismic profiles in the western Qaidam Basin have revealed any extensional faults during the Early Tertiary. Meng and Fang (2008) suggested that the Cenozoic tectonic subsidence of the Qaidam Basin resulted from crustal folding or buckling in response to regional horizontal compression. However, the seismic profiles across the whole Qaidam Basin imply that the magnitude of Cenozoic upper crustal shortening decreases eastward across the basin from $>48 \%$ in the west to $<1 \%$ in the east (Yin et al., 2008), whereas the present day basin is wider to the west and relatively narrow to the east. This phenomenon is difficult to explain only by crustal folding or buckling.

To summarize, despite the large number of models that have been proposed, few studies took the left-lateral strike-slip factor into account when considering the relationship between the Qaidam Basin and the Eastern Kunlun Mountains.

\subsection{Strike-slip tectonics and northward growth of western segment of Kunlun Fault.}

The Qaidam Basin is bordered to the northwest by the Altyn Tagh Fault which has been active since the Early or Middle Eocene (Jolivet et al., 1999, 2001; Yin et al., 2002). In addition, despite that Chen et al. (2002) concluded that the Qaidam Basin experienced an over $20^{\circ}$ clockwise rotation during the Neogene resulting in differential shortening in the Nan Shan fold 
and thrust belt (Fig. 1), Dupont-Nivet et al. $(2003,2004)$ suggested that the Nan Shan fold and thrust belt and the Qaidam Basin did not experience any vertical axis rotation during the Neogene. As the limit between the thick, rigid Tarim block and the more deformable Qaidam Basin, the Altyn Tagh Fault is considered stable in time. Consequently, the deformation in the SW Qaidam Basin and the western segment of the Kunlun Fault should be bordered and limited to the NW by the Altyn Tagh Fault. When considering the geometric relation between the Altyn Tagh Fault and Kunlun Fault, the western Kunlun fault segment has to rotate northward: the left-lateral movement on the Altyn Tagh is progressively driving the connection point between that fault and the Kunlun fault towards the east. For the Kunlun Fault to be able to continuously act as a strike-slip fault, it would jump backwards towards its initial position creating a new strike-slip segment. As mentioned above, the distribution and focal mechanisms of earthquakes indicate that the active tectonic pattern along the Kunlun Fault is characterized by left-lateral strike-slip motion. However, in the SW Qaidam Basin and the Qimen Tagh Range the deformation is accommodated by NW-SE directed thrust faults associated to a limited left-lateral strike-slip component (Fig. 3). In addition, the geomorphological WNW trending linear structures in the Qimen Tagh Range (Fig. 5) and deformed Pleistocene sequences in the Adatan Valley (Figs. 8 and 9) record the left-lateral strike-slip movements within the Qimen Tagh Range since the Pleistocene. Finally, the overall tectonic and structural architecture within the SW Qaidam Basin is dominated by a series of high angle faults. The sudden variation in sediment thickness marked by the offset of the isopachs on both side of the faults (Fig. 10) associated to the growth strata and the positive flower structures generated by movements on those faults (Figs. 11, 12 and 13), indicate Early Miocene left-lateral strike-slip faulting in SW Qaidam Basin. 
Synthesizes the above analysis, we thus propose that the Late Neogene northward growth of the convex-northward structures in the Qimen Tagh Range and SW Qaidam Basin (northern margin of the Tibetan Plateau) is driven by progressive northward migration of the left-lateral strike-slip Kunlun Fault (Fig. 14).

Around the Early Miocene, the left-lateral strike-slip faulting in the Kunlun Fault Zone initiated. This motion lead to E-W extension along the northern margin of the Tibetan Plateau and the deeply rooted strike-slip faults were acting as pathways for the shoshonitic magmas (Jolivet et al., 2003), leucogranites and rhyolites (Zhang et al., 2012) to reach the surface. During that period, the parallel Kunbei, Arlar and Hongliuquan faults (designated below as the Kunbei fault system) were forming the western segment of the Kunlun Fault, located in the same position as the present-day Kunlun Fault with a nearly E-W striking trend. The left-lateral movement between the Qiangtang-Bayan Har and Qaidam blocks caused the en-échelon arrangement of the faults and generated the growth strata recording the onset time (Early Miocene) of fault activation. Following this initial phase, the Kunbei fault system, progressively rotated clockwise and migrated northwards, forming the successive high-angle left-lateral compressional faults now observed in the SW Qaidam Basin. In order to maintain the strike-slip motion along the western segment of the Kunlun Fault, a new strike-slip fault system, the Qimen Tagh fault system (including the MQF and SQF) developed during the Pleistocene in place of the older western Kunlun Fault segment that migrated northward. This second phase is recorded by the deformed coarse-grain Pleistocene deposits in the Adatan Valley. This newly formed Qimen Tagh strike-slip fault segment again migrated northwards and progressively rotated clockwise forming the present-day Qimen Tagh prism. Another new strike-slip fault segment developed on 
the western end of the Kunlun Fault, replacing the previous one. During the process of northward migration of these left-lateral strike-slip faults (the Kunbei Fault, the Arlar Fault, the Hongliuquan Fault, the MQF and the SQF), their motion changed from left-lateral strike-slip to nearly NE-SW compressional motion. The characteristic northward-convex bow-like shape of the Kubei fault system and of the Qimen Tagh prism is governed by the strike-slip motion along the Altyn Tagh Fault to the northwest. The northward migration of the western segment of the Kunlun Fault explains the lack of Early Miocene sediment records at the present day location of this western segment that would relate to the initiation of the Kunlun Fault.

The model proposed above is an evolution of the previously proposed transpressional model (Meyer et al., 1998; Jolivet et al., 2001; Tapponnier et al., 2001). It identifies the Kunbei fault system and Qimen Tagh fault systems as the western segment of the Kunlun Fault Zone and describes their progressive northward migration since Early Miocene. Their initiation as strike-slip faults explains the present-day steepness of the fault planes.

Based on the analysis of geological features in the Jingyu Basin (North Tibet) and the intrusion of Tertiary to Quaternary shoshonites along the western segment of the Eastern Kunlun Mountains, Meyer et al. (1998) and Jolivet et al. (2003) suggested that the strike-slip Kunlun Fault initated during the Early Neogene. Recently, after detailed geochemistry and geochronology studies on the Miocene leucogranites and rhyolites found in the Hoh Xil Lake area (north of the Kunlun Fault) (Fig. 1), Zhang et al. (2012) suggested that the dehydration melting in this area was probably triggered by localized E - W stretching decompression within the left-lateral strike-slip Kunlun Fault system around 15 Ma. Meanwhile, Duvall et al. (2013) and Yin (2010) also considered that the left-lateral East Kunlun transpressional system initiated around 30 to $20 \mathrm{Ma}$ as 
a response to the collision between India and Asia. These ages of initial faulting in the Eastern Kunlun Mountains are roughly consistent with our results.

In addition, from the data described above, the boundary between the SW Qaidam Basin and the Eastern Kunlun Mountains is characterized, since the Early Miocene by a series of northward migrating and eastward rotating left-lateral strike-slip faults rather than by a continuous northward thrusting (e.g. Burchfiel et al., 1989; Meyer et al., 1998) or southward thrusting system (e.g. Yin et al., 2007; Wang et al., 2011). Consequently, the SW Qaidam Basin did not suffer a large amount of N-S compression and shortening before the Early Miocene. This observation is compatible with the Paleo-Qaidam model of Yin et al., (2008) which suggests the existence, during the Paleogene, of a large topographic depression encompassing the Hoh Xil Basin to the south and the Qaidam Basin to the north. This wide basin was partitioned by the uplift of the Eastern Kunlun Mountains during Late Oligocene - Early Miocene times. 


\section{Conclusions}

The Eastern Kunlun Mountains and adjacent Qaidam Basin present one of the largest topographic gradients in the Tibetan Plateau. In that respect, determining the tectonic relations between the Qaidam Basin and the Eastern Kunlun Mountains and deciphering the complex tectonic architecture of the western segment of the Kunlun Fault has major implications in understanding the tectonic, sedimentary and geomorphic Cenozoic history of North Tibet.

The distribution and focal mechanisms of earthquakes presented in this study indicate that the active tectonic pattern in the SW Qaidam Basin and the Qimen Tagh Range is dominated by transpressional structures while that of the Eastern Kunlun Mountains is characterized by left-lateral strike-slip faulting. Geomorphological interpretation of remote sensing images shows that the Qimen Tagh Range is affected by obvious WNW trending linear structures which relate to left-lateral strike-slip motion. The deformed Pleistocene sediments within the Adatan Valley strongly suggest strike-slip faulting along those WNW trending faults during the Pleistocene. To the north, in the SW Qaidam Basin, the offset isopachs of the Late Eocene sediments and the en-échelon arrangement of Kunbei, Arlar and Hongliuquan faults again indicate left-lateral strike-slip faulting. This, associated to growth strata, implies an Early Miocene onset age for the left-lateral strike-slip deformation of the Kunbei fault system in the SW Qaidam Basin. This tectonic pattern and the southwards younging of the left-lateral strike-slip phases lead us to identify the Kunbei Fault system and the Qimen Tagh faults system as former western segments of the Kunlun Fault once located further south in the present-day location of that fault. These faults gradually migrated northward since the Early Miocene while their kinematics changed from 
left-lateral strike-slip motion to NE-SW compression.

We conclude that the SW Qaidam Basin has been bordered by a series of strike-slip faults to the south since the Early Miocene, rather than by a continuous northward thrusting or southward thrusting system. The SW Qaidam Basin did not suffer major N-S compression and shortening before the Early Miocene. 


\section{Acknowledgments}

This study was financially supported by grants from the National Science and Technology Major Project (2011E-03). Marc Jolivet was supported by the Darius Program, the French Chinese Egide Cai Yuanpei Program and the French Centre National de la Recherche Scientifique (CNRS), Institut National des Sciences de l'Univers (INSU) Syster Program. We would like to thank Editor Mian Liu and anonymous reviewers who provided constructive and thoughtful comments that helped improving the manuscript.

\section{Figure Caption}

Fig. 1. Digital topographic map of the western Qaidam Basin and surrounding area. Topography from SRTM data.

Fig. 2. Geological map of the Qimen Tagh Range and SW Qaidam Basin. See Fig. 1 for location and the text for discussion. Modified after the Kulangmiqiti J46C003001 1:250,000 geological map (IGSQP, 2004).

Fig. 3. General topographic map of the Qaidam Basin and Eastern Kunlun Mountains with background seismicity from the China Earthquake Networks Center (CENC) from 1rst January 1970 to 1 rst January $2011(\mathrm{M}>3)$. 
Fig. 4. Depth-frequency distribution of earthquakes within the study area. Data from the China Earthquakes Networks Center (CENC), 1rst January 1970 to 1rst January 2011 with M > 3. Two seismic profiles (AA' (a) and BB' (b) (See location on Fig.3) are investigated with (left) depth distribution of earthquakes and (right) depth - frequency distribution of seismic events. See text for discussion.

Fig. 5. Remote sensing image from Landsat 5 on December 5, 2008 (USGS) (a) and SRTM digital topography map (b) of the Qimen Tagh Range. The red solid lines show the main tectonic structures. See the location in Fig. 1.

Fig. 6. Un-interpreted (a) and interpreted SPOT-5 image (b) (Google Earth) centered on the western part of the Middle Qimen Tagh Fault (MQF). See the location in Fig. 5. The red solid lines indicate the fault segments imaged by fault scarps on the surface. The dashed line represents the blind fault covered by the Quaternary sediments. The fault scarps in en-échelon arrangement indicates a left-lateral strike-slip movement on the MQF.

Fig.7. Un-interpreted (a) and interpreted SPOT-5 image (b) (Google Earth) centered on the eastern part of the Middle Qimen Tagh fault. See the location in Fig. 5. The red dash line indicates the linear fault linking the Qimen Tagh fault system in the west with the Eastern Kunlun Fault system in the east.

Fig. 8. Cenozoic formations within the Adatan Valley. (a) General view of the Qimen Tagh Range. 
The picture, taken from $\sim 10 \mathrm{~km}$ south of the Atantihan river checkpoint, shows the strong relief between the Adatan Valley and the mountains bordered by a series of triangular facets and fault scarps belonging to the MQF. The foothills domain is represented by Cenozoic strata which are deformed and pushed into gentle folds. See the location in Fig. 9. (b) Uplifted Pleistocene series covered by Holocene tillites (left) and general stratigraphic column (right). See the photographs' location in Fig. 8.

Fig. 9. Geological sketch of the Qimen Tagh Range showing the distribution of the Cenozoic series. Modified after the Kulangmiqiti J46C003001 1:250,000 geological map (IGSQP, 2004) and the Ayakekumu J45C003004 1:250,000 geological map (IGSSP, 2003). See the location in Fig. 2.

Fig. 10. Isopach map of the Upper Xiaganchaigou Formation $\left(E_{3}^{2} \mathrm{xg}\right)$. Three major faults (the Kunbei Fault, the Arlar Fault and the Hongliuquan Fault) are also marked on the isopach map based on seismic data. These data were acquired by the Qinghai Oilfield Company (China) who compiled information from thousands of drill holes and a dense network of seismic profiles in recent years. Note the offset of the 400 isopach line controlled by the faults and indicating the left-lateral strike-slip faulting of these faults.

Fig. 11. Seismic profile C - C' in the SW Qaidam Basin. See the location in Figs. 2 and 10. Note that the thickness of the Paleocene to Eocene strata shows a sharp difference between both sides of the Arlar Fault. The growth strata associated to the positive flower structure started to develop during the initial deposition of the Early Miocene unit $\left(\mathrm{N}_{2}{ }^{1} \mathrm{xy}\right)$, which suggests that the strike - slip 
movement on the Arlar Fault initiated during the deposition of this unit.

Fig. 12. Seismic section D - D' in the SW Qaidam Basin. See Figs. 2 and 10 for location. Note that the strata below the Shangyoushashan Fm. $\left(\mathrm{N}_{2}{ }^{1} \mathrm{xy}\right)$ keep a constant thickness in the section, while the strata above it are thinning northward. The thickness of the Paleocene to Eocene strata shows a sharp difference between both sides of the Arlar Fault. Meanwhile, Early Miocene growth strata above the Arlar and Hongliuquan faults indicate the onset of left-lateral strike-slip faulting during the Early Miocene.

Fig. 13. Seismic profile E - E' in the SW Qaidam Basin. See the location in Figs. 2 and 10. Note that the thickness of the Paleocene to Eocene strata shows a sharp difference between both sides of the Kunbei Fault. Meanwhile, Early Miocene growth strata again indicate an onset of left-lateral strike-slip faulting during the Early Miocene.

Fig. 14. Tectonic evolution of the Qimen Tagh Range and the SW Qaidam Basin since the Early Neogene. See the text for discussion.

\section{References}

Bally, A.W., Chou, I.-M., Clayton, R., Eugster, H.P., Kidwell, S., Meckel, L.D., Ryder, R.T., Watts, A.B., and Wilson, A.A., 1986. Notes on Sedimentary Basins in China-Report of the 
American Sedimentary Basins delegationto the People's Republic of China. U.S. Geological Survey Open-File Report, 108 pp. 86-327.

Burchfiel, B.C., Quidong, D., Molnar, P., Royden, L., Yipeng, W., Peizhen, Z., Weiqi, Z., 1989. Intracrustal detachment within zones of continental deformation. Geology 17, 748-752. doi: 10.1130/0091-7613(1989) 017<0448:IDWZOC>2.3.CO;2.

Chen, W., Chen, C., L Nábelek, J., 1999. Present-day deformation of the Qaidam basin with implications for intra-continental tectonics. Tectonophysics 305, 165-181, doi: 10.1016/S0040-1951(99)00006-2.

Christophoul, F., Baby, P., Dávila, C., 2002. Stratigraphic responses to a major tectonic event in a foreland basin: the Ecuadorian Oriente Basin from Eocene to Oligocene times.

Tectonophysics 345, 281-298.

Chu, R., Zhu, L., Helmberger, D.V., 2009. Determination of earthquake focal depths and source time functions in central Asia using teleseismicPwaveforms. Geophysical Research Letters 36, doi: 10.1029/2009GL039494.

Clark, M.K., Farley, K.A., Zheng, D., Wang, Z., Duvall, A.R., 2010. Early Cenozoic faulting of the northern Tibetan Plateau margin from apatite (U-Th)/He ages. Earth and Planetary Science Letters 296, 78-88, doi:10.1016/j.epsl.2010.04.051.

Deng, T., Wang, X. M., 2004a. New material of the Neogene rhinocerotids from the Qaidam Basin in Qinghai, China, Vertebr. PalAsiat 42(3), 216-229.

Deng, T., Wang, X. M., 2004b. Late Miocene Hipparion (Equidae, Mammalia) of eastern Qaidam Basin in Qinghai, China, Vertebr. PalAsiat 42 (4), 316-333. 
Dupont-Nivet, G., Butler, R.F., Yin, A., Chen, X., 2003. Paleomagnetism indicates no Neogene vertical axis rotations of the northeastern Tibetan Plateau. J. geophys. Res 108, 2386, doi: 10.1029/2003JB002399.

Dupont-Nivet, G., Robinson, D., Butler, R.F., Yin, A., Melosh, H.J., 2004. Concentration of crustal displacement along a weak Altyn Tagh fault: Evidence from paleomagnetism of the northern Tibetan Plateau. Tectonics 23, TC1020, doi: 10.1029/2002TC001397, 2004.

Durand-Riard, P., Shaw, J.H., Plesch, A., Lufadeju, G., 2013. Enabling 3D geomechanical restoration of strike-and oblique-slip faults using geological constraints, with applications to the deep-water Niger Delta. Journal of Structural Geology, 48: 33-44, doi: 10.1016/j.jsg.2012.12.009.

Duvall, A.R., Clark, M.K., Kirby, E., Farley, K.A., Craddock, W.H., Li, C., Yuan, D.-Y., 2013. Low-temperature thermochronometry along the Kunlun and Haiyuan Faults, NE Tibetan Plateau: Evidence for kinematic change during late-stage orogenesis. Tectonics 32, 1190-1211, doi:10.1002/tect.20072.

Fang, X., Zhang, W., Meng, Q., Gao, J., Wang, X., King, J., Song, C., Dai, S., Miao, Y., 2007. High-resolution magnetostratigraphy of the Neogene Huaitoutala section in the eastern Qaidam Basin on the NE Tibetan Plateau, Qinghai Province, China and its implication on tectonic uplift of the NE Tibetan Plateau. Earth and Planetary Science Letters 258, 293-306, doi:10.1016/j.epsl.2007.03.042.

Fu, B.H., Awata, Y., Du, J.G., He, W.G., 2005. Late Quaternary systematic stream offsets caused by repeated large seismic events along the Kunlun fault, northern Tibet. Geomorphology 71, 278-292, doi:10.1016/j.geomorph.2005.03.001. 
Fu, B. H., Awata, Y., 2007. Displacement and timing of left-lateral faulting in the Kunlun Fault Zone, northern Tibet, inferred from geologic and geomorphic features. Journal of Asian Earth Sciences 29, 253-265, doi:10.1016/j.jseaes.2006.03.004.

Fu J., 2008. Division of Quaternary sedimentary types in Adatan area, Xinjiang. World Nuclear Geoscience 25(2), 94-97(in Chinese with English abstract).

Gao, J., Li, S., Dai, S., Li, A., Peng, Y., 2009. Constraints of tectonic evolution in provenance from detrital zircon fission-track data of Cenozoic strata of Xichagou district in western Qaidam basin: Journal of Lanzhou University (Natural Sciences), 45 (3), 1-7, doi: 0455-2059(2009)03-0001-07 (in Chinese with English abstract).

Guo, J., Lin, A., Sun, G., Zheng, J., 2007. Surface ruptures associated with the 1937 M 7.5 Tuosuo Lake and the 1963 M 7.0 Alake Lake earthquakes and the paleoseismicity along the Tuosuo Lake Segment of the Kunlun Fault, Northern Tibet. Bulletin of the Seismological Society of America 97, 474-496, doi: 10.1785/0120050103.

Harkins, N., Kirby, E., 2008. Fluvial terrace riser degradation and determination of slip rates on strike-slip faults: An example from the Kunlun fault, China. Geophysical Research Letters 35, doi: 10.1029/2007GL033073.

Hinsch, R., Decker, K., Peresson, H., 2005. 3-D seismic interpretation and structural modeling in the Vienna Basin: implications for Miocene to recent kinematics. Austrian J. Earth Sci 97, $38-50$.

Huang, H., Huang, Q., Ma, Y., 1996. Geology of Qaidam Basin and its petroleum prediction. Geological Publishing House, Beijing pp. 1-257 (in Chinese with English abstract). 
Huo, G.M., 1990. Petroleum geology of China: Oil fields in Qianghai and Xizang. Chinese Petroleum Industry Press, Beijing 14, pp. 1-483 (in Chinese with English abstract).

IGSSP (Insititute of Geological Survey of Shanxi Province), 2003. The Report of Regional

Geological Survey at Scale 1:250000. P.R.C. China Industry Press, pp. 1-274 (in Chinese).

IGSQP (Insititute of Geological Survey of Qinhai Province), 2004. The Report of Regional Geological Survey at Scale 1:250000. P.R.C. China Industry Press, pp. 1-386 (in Chinese).

Jolivet, M., Roger, F., Arnaud, N., Brunel, M., Tapponnier, P., Seward, D., 1999. Histoire de l'exhumation de l'Altun Shan: indications sur l'âge de la subduction du bloc du Tarim sous le système de l'Altyn Tagh (Nord Tibet). C.R. Acad. Sci. Paris 329, 749-755, doi: $10.1016 / \mathrm{S} 1251-8050(00) 88495-5$

Jolivet, M., Brunel, M., Seward, D., Xu, Z., Yang, J., Roger, F., Tapponnier, P., Malavieille, J., Arnaud, N., Wu, C., 2001. Mesozoic and Cenozoic tectonics of the northern edge of the Tibetan plateau: fission-track constraints. Tectonophysics 343, 111-134, doi: 10.1016/S0040-1951(01)00196-2.

Jolivet, M., Brunel, M., Seward, D., Xu, Z., Yang, J., Malavieille, J., Roger, F., Leyreloup, A., Arnaud, N., Wu, C., 2003. Neogene extension and volcanism in the Kunlun Fault Zone, northern Tibet: New constraints on the age of the Kunlun Fault. Tectonics 22, 1052, doi: $10.1029 / 2002 \mathrm{TC} 001428$.

Jolivet, M., Arzhannikov, S., Chauvet, A., Arzhannikova, A., Vassallo, R., Kulagina, N., Akulova, V., 2013. Accomodating large-scale intracontinental extension and compression in a single stress-field: A key example from the Baikal Rift System. Gondwana Research, 24(3), 918-935, doi:10.1016/j.gr.2012.07.017. 
Jordan, T.E., 1981. Thrust loads and foreland basin evolution, Cretaceous, western United States. AAPG bulletin 65, 2506-2520.

Ke, X., Ji, J., Zhang, K., Kou, X., Song, B., Wang, C., 2013. Magnetostratigraphy and Anisotropy of Magnetic Susceptibility of the Lulehe Formation in the Northeastern Qaidam Basin. Acta Geologica Sinica-English Edition 87, 576-587, doi: 10.1111/1755-6724.12069.

Kidd, W.S.F., Molnar, P., 1988. Quaternary and active faulting observed on the 1985 Academia Sinica--Royal society geotraverse of Tibet. Philosophical Transactions of the Royal Society of London. Series A, Mathematical and Physical Sciences 327(1594), 337-363, doi: 10.1098/rsta.1988.0133.

Kirby, E., Harkins, N., Wang, E., Shi, X., Fan, C., Burbank, D., 2007. Slip rate gradients along the eastern Kunlun fault. Tectonics 26, doi: 10.1029/2006TC002033.

Lin, A., Fu, B., Guo, J., Zeng, Q., Dang, G., He, W., Zhao, Y., 2002. Co-seismic strike-slip and rupture length produced by the 2001 Ms 8.1 Central Kunlun earthquake. Science 296, 2015-2017, doi: 10.1126/science.107087.

Lin, A., Guo, J., 2008. Nonuniform Slip Rate and Millennial Recurrence Interval of Large Earthquakes along the Eastern Segment of the Kunlun Fault, Northern Tibet. Bulletin of the Seismological Society of America 98, 2866-2878, doi: 10.1785/0120070193.

Liu, Y.J., Genser, J., Neubauer, F., Jin, W., Ge, X.H., Handler, R., Takasu, A., 2005. ${ }^{40} \mathrm{Ar} /{ }^{39} \mathrm{Ar}$ mineral ages from basement rocks in the Eastern Kunlun Mountains, NW China, and their tectonic implications. Tectonophysics 398, 199-224, doi: 10.1016/j.tecto.2005.02.007. 
Lu, H., Xiong, S., 2009. Magnetostratigraphy of the Dahonggou section, northern Qaidam Basin and its bearing on Cenozoic tectonic evolution of the Qilian Shan and Altyn Tagh Fault. Earth and Planetary Science Letters 288, 539-550, doi:10.1016/j.epsl.2009.10.016.

Macedo, J., Marshak, S., 1999. Controls on the geometry of fold-thrust belt salients. Geological Society of America Bulletin 111, 1808-1822, doi: 10.1130/0016-7606(1999) 111<1808:COTGOF>2.3.CO;2.

McQuarrie, N., 2004. Crustal scale geometry of the Zagros fold-thrust belt, Iran. Journal of Structural Geology 26, 519-535, doi:10.1016/j.jsg.2003.08.009.

Meng, Q.R., Fang, X., 2008. Cenozoic tectonic development of the Qaidam Basin in the northeastern Tibetan Plateau. Geological Society of America Special Papers 444, 1-24, doi: $10.1130 / 2008.2444(01)$

Meyer, B., Tapponnier, P., Bourjot, L., Metivier, F., Gaudemer, Y., Peltzer, G., Shunmin, G., Zhitai, C., 1998. Crustal thickening in Gansu-Qinghai, lithospheric mantle subduction, and oblique, strike-slip controlled growth of the Tibet plateau. Geophysical Journal International 135, 1-47, doi: 10.1046/j.1365-246X.1998.00567.x.

Mock, C., Arnaud, N.O., Cantagrel, J.M., 1999. An early unroofing in northeastern Tibet? Constraints from ${ }^{40} \mathrm{Ar} /{ }^{39} \mathrm{Ar}$ thermochronology on granitoids from the Eastern Kunlun Mountains (Qianghai, NW China). Earth and Planetary Science Letters 171, 107-122, doi: 10.1016/S0012-821X(99)00133-8.

Pei, J., Sun, Z., Wang, X., Zhao, Y., Ge, X., Guo, X., Li, H., Si, J., 2009. Evidence for Tibetan plateau uplift in Qaidam Basin before Eocene-Oligocene boundary and its climatic implications. Journal of Earth Science 20, 430-437, doi: 10.1007/s12583-009-0035-y. 
Peltzer, G., Crampé, F., King, G., 1999. Evidence of nonlinear elasticity of the crust from the

Mw7. 6 Manyi (Tibet) earthquake. Science 286, 272-276, doi:10.1126/science.286.5438.272.

QBGMR (Qinhai Bureau of Geology Mineral Resources), 1991. Regional Geology of Qinghai Province. Geological Publishing House, Beijing, pp. 1-662 (in Chinese).

Qiu, N., 2002. Tectono-thermal evolution of the Qaidam Basin, China: evidence from Ro and apatite fission track data. Petroleum Geoscience 8, 279-285, doi: 10.1144/petgeo.8.3.279.

Sepehr, M., Cosgrove, J., 2004. Structural framework of the Zagros fold-thrust belt, Iran. Marine and Petroleum Geology 21, 829-843, doi:10.1016/j.marpetgeo.2003.07.006.

Sobel, E.R., Hilley, G.E., Strecker, M.R., 2003. Formation of internally drained contractional basins by aridity-limited bedrock incision. J. Geophys. Res 108, 25, doi: 10.1029/2002JB001883.

Song, T., Wang, X., 1993. Structural styles and stratigraphic patterns of syndepositional faults in a contractional setting: Examples from Quaidam basin, northwestern China. AAPG bulletin 77, 102-117.

Song, C. H. 2006. Tectonic uplift and Cenozoic sedimentary evolution in the northern margin of the Tibetan Plateau. [Dissertation]. Lanzhou University, Lanzhou. 85-123 (in Chinese with English abstract).Sun, Z.M., Yang, Z.Y., Pei, J.L., Ge, X.H., Wang, X.S., Yang, T.S., Li, W.M., Yuan, S.H., 2005. Magnetostratigraphy of Paleogene sediments from northern Qaidam Basin, China: implications for tectonic uplift and block rotation in northern Tibetan plateau. Earth and Planetary Science Letters 237, 635-646, doi: 10.1016/j.eps1.2005.07.007. 
Sun, Z. C., Jing M. C., Sun, N. D., Lu Y.L., Cao, L., 2007. Discussion on boundary between the upper and lower members of Xiaganchaigou Formation of Paleogene in Well Kun-2, Qaidam Basin. Journal of Palaeogeography, 9(6), 611-618 (in Chinese with English abstract).

Suppe, J., Chou, G.T., Hook, S.C., 1992. Rates of folding and faulting determined from growth strata, Thrust tectonics. Springer, pp. 105-121.

Tapponnier, P., Zhiqin, X., Roger, F., Meyer, B., Arnaud, N., Wittlinger, G., Jingsui, Y., 2001. Oblique stepwise rise and growth of the Tibet Plateau. Science 294, 1671-1677, doi: 10.1126/science. 105978 .

Taylor, M., Yin, A., 2009. Active structures of the Himalayan-Tibetan orogen and their relationships to earthquake distribution, contemporary strain field, and Cenozoic volcanism. Geosphere 5, 199-214, doi: 10.1130/GES00217.1.

Van Der Woerd, J., Ryerson, F.J., Tapponnier, P., Gaudemer, Y., Finkel, R., Mériaux, A.S., Caffee, M., Guoguang, Z., Qunlu, H., 1998. Holocene left-slip rate determined by cosmogenic surface dating on the Xidatan segment of the Kunlun fault (Qinghai, China). Geology 26, 695-698, doi: 10.1130/GES00217.1.

Velasco, A.A., Ammon, C.J., Beck, S.L., 2000. Broadband source modeling of the November 8, 1997, Tibet $\left(M_{w}=7.5\right)$ earthquake and its tectonic implications. Journal of Geophysical Research: Solid Earth (1978-2012) 105 (B12), 28065-28080, doi: 10.1029/2000JB900282.

Vergés, J., Marzo, M., Muñoz, J., 2002. Growth strata in foreland settings. Sedimentary Geology 146, 1-9, doi: 10.1016/S0037-0738(01)00162-2. 
Wang, Q., Zhang, P.Z., Freymueller, J.T., Bilham, R., Larson, K.M., Lai, X., You, X., Niu, Z., Wu, J., Li, Y., 2001. Present-day crustal deformation in China constrained by global positioning system measurements. Science 294, 574-577, doi: 10.1126/science.1063647.

Wang, F., L., C. H., Li, Q., Yeh, M. W., Wan, J., Zheng, D., Wang, E., 2004a. Onset timing of significant unroofing around Qaidam basin, northern Tibet, China: constraints from ${ }^{40} \mathrm{Ar} /{ }^{39} \mathrm{Ar}$ and FT thermochronology on granitoids. Journal of Asian Earth Sciences 24, 59-69, doi: 10.1016/j.jseaes.2003.07.004.

Wang, S. J., Bai, Y. S., Hao, P., Chang, G. H., Bao, G. P., 2004b. Discovery of fresh water Gastropoda fossils in Ancient Neoteric period and its geological significance in Adatan basin. Northwestern Geology 37(3), 21-23 (in Chinese with English abstract).

Wang, E., Xu, F.Y., Zhou, J.X., Wan, J., Burchfiel, B.C., 2006. Eastward migration of the Qaidam basin and its implications for Cenozoic evolution of the Altyn Tagh fault and associated river systems. Geological Society of America Bulletin 118, 349-365, doi: 10.1130/B25778.1.

Wang, S. J., Bai, Y. S., Xu, Y. F., Zhang, K. C., Chang, G. H., 2007. Tectonic Evolution of the Adatan Basin in Late Paleogene. Northwestern Geology 40(4), 53-57 (in Chinese with English abstract).

Wang, Y.D., Nie, J.S., Zhang, T., Sun, G.Q., Yang, X., Liu, Y.H., Liu, X.W., 2010. Cenozoic tectonic evolution in the western Qaidam Basin inferred from subsurface data. Geosciences Journal 14, 335-344, doi: 10.1007/s12303-010-0033-1.

Wang, C.S., Gao, R., Yin, A., Wang, H., Zhang, Y.X., Guo, T.L., Li, Q.S., Li, Y.L., 2011. A mid-crustal strain-transfer model for continental deformation: A new perspective from 
high-resolution deep seismic-reflection profiling across NE Tibet. Earth and Planetary Science Letters 306, 279-288, doi: 10.1016/j.epsl.2011.04.010.

Xia, W.C., Zhang, N., Yuan, X.P., Fan, L.S., Zhang, B.S., 2001. Cenozoic Qaidam basin, China: A stronger tectonic inversed, extensional rifted basin. AAPG bulletin 85, 715-736.

Xu, X.W., Chen, W.B., Ma, W.T., Yu, G.H., Chen, G.H., 2002. Surface rupture of the Kunlunshan earthquake (Ms 8.1), northern Tibetan plateau, China. Seismological Research Letters 73, 884-892.

Yang, F., Ma, Z.Q., Xu, T.C., Ye, S.J., 1992. A Tertiary paleomagnetic stratigraphic profile in Qaidam basin. Acta Petrolei Sinica 13(2), 97-101(in Chinese with English abstract).

Ye, D., 1997. Tertiary in Petroliferous Regions of China. Petroleum Inductry Press, Beijing, pp. 1-374 (in Chinese with English abstract).

Yin, A., Harrison, T.M., 2000. Geologic evolution of the Himalayan-Tibetan orogen. Annual Review of Earth and Planetary Sciences 28, 211-280, doi: 10.1146/annurev.earth.28.1.211.

Yin, A., Rumelhart, P.E., Cowgill, E., Butler, R., Harrison, T.M., Ingersoll, R.V., Cooper, K., Zhang, Q., and Wang, X. F., 2002. Tectonic history of the Altyn Tagh fault system in northern Tibet inferred from Cenozoic sedimentation. Geological Society of America Bulletin 114, 1257-1295, doi: 10.1130/0016-7606(2002)114<1257: THOTAT>2.0.CO;2.

Yin, A., Dang, Y.Q., Zhang, M., McRivette, M.W., Burgess, W.P., Chen, X.H., 2007. Cenozoic tectonic evolution of Qaidam basin and its surrounding regions (part 2): Wedge tectonics in southern Qaidam basin and the Eastern Kunlun Mountains. Geological Society of America Special Papers 433, 369-390, doi: 10.1130/2007.2433(18). 
Yin, A., Dang, Y.Q., Zhang, M., Chen, X.H., McRivette, M.W., 2008. Cenozoic tectonic evolution of the Qaidam basin and its surrounding regions (Part 3): Structural geology, sedimentation, and regional tectonic reconstruction. Geological Society of America Bulletin 120, 847-876, doi: 10.1130/B26232.1.

Yin, A., 2010. Cenozoic tectonic evolution of Asia: A preliminary synthesis. Tectonophysics 488, 293-325, doi:10.1016/j.tecto.2009.06.002.

Yuan, W.M., Dong, J.Q., Wang, S.C., Carter, A., 2006. Apatite fission track evidence for Neogene uplift in the eastern Kunlun Mountains, northern Qinghai-Tibet Plateau, China. Journal of Asian Earth Sciences 27, 847-856, doi: 10.1016/j.jseaes.2005.09.002.

Zhang, Y.X., Che, Z.C., Liu, L., Luo, J.L., 1996. Tertiary in the Kumkol Basin, Xinjiang. Regional Geology of China 4, 311-316 (in Chinese with English abstract).

Zhang, P.Z., Shen, Z., Wang, M., Gan, W., Bürgmann, R., Molnar, P., Wang, Q., Niu, Z., Sun, J., Wu, J., 2004. Continuous deformation of the Tibetan Plateau from global positioning system data. Geology 32, 809-812, doi: 10.1130/G20554.1.

Zhang, W., 2006. The high precise Cenozoic magnetostratigraphy of the Qaidam Basin and uplift of the Northern Tibetan plateau. [Doctoral dissertation]. Lanzhou University, Lanzhou. 95-105 (in Chinese with English abstract).

Zhang, Z., Klemperer, S., Bai, Z., Chen, Y., Teng, J., 2011. Crustal structure of the Paleozoic Kunlun orogeny from an active-source seismic profile between Moba and Guide in East Tibet, China. Gondwana Research 19, 994-1007, doi: 10.1016/j.gr.2010.09.008.

Zhang, L.Y., Ding, L., Yang, D., Xu, Q., Cai, F.L., Liu, D.L., 2012. Origin of middle Miocene leucogranites and rhyolites on the Tibetan Plateau: Constraints on the timing of crustal 
thickening and uplift of its northern boundary. Chinese Science Bulletin 57, 511-524, doi: 10.1007/s11434-011-4813-4.

Zhao, J., Mooney, W.D., Zhang, X., Li, Z., Jin, Z., Okaya, N., 2006. Crustal structure across the Altyn Tagh Range at the northern margin of the Tibetan plateau and tectonic implications. Earth and Planetary Science Letters 241, 804-814, doi:10.1016/j.eps1.2005.11.003. 


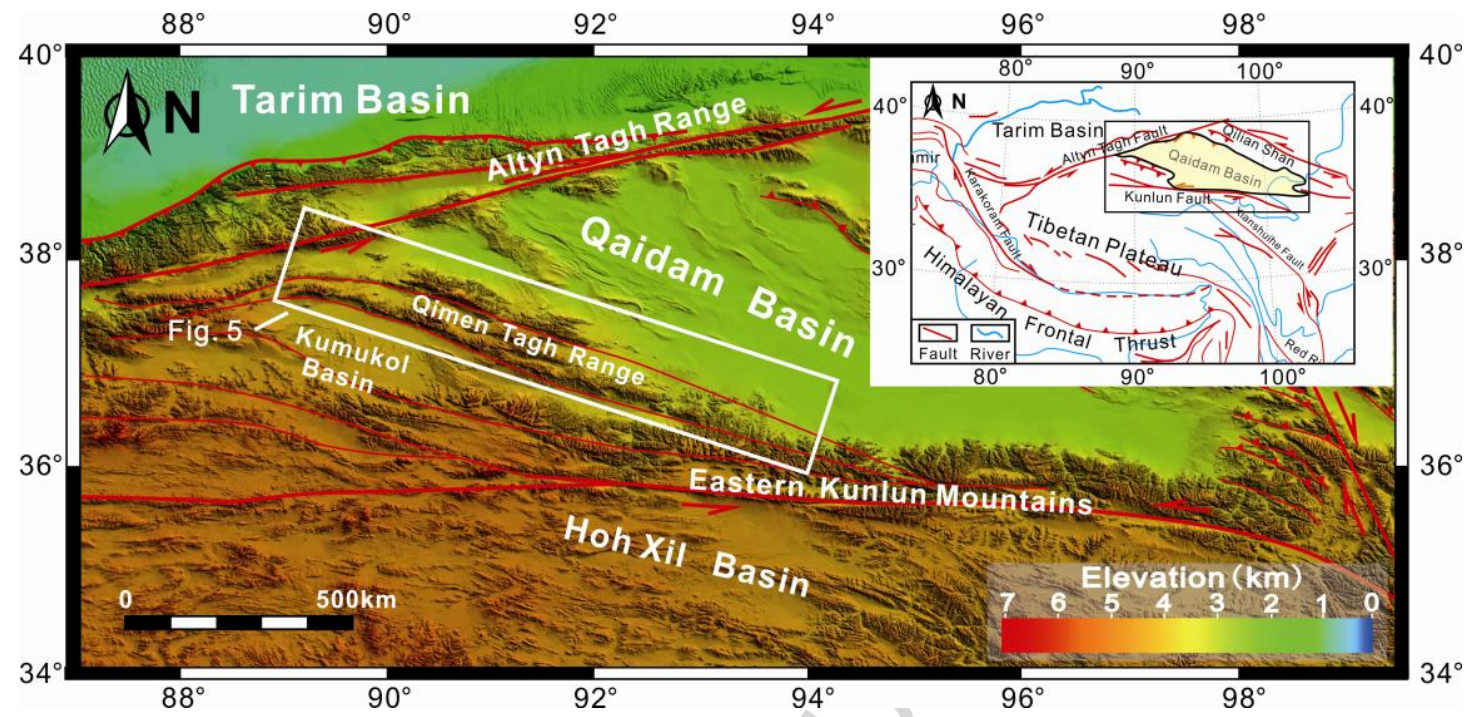

Fig1 


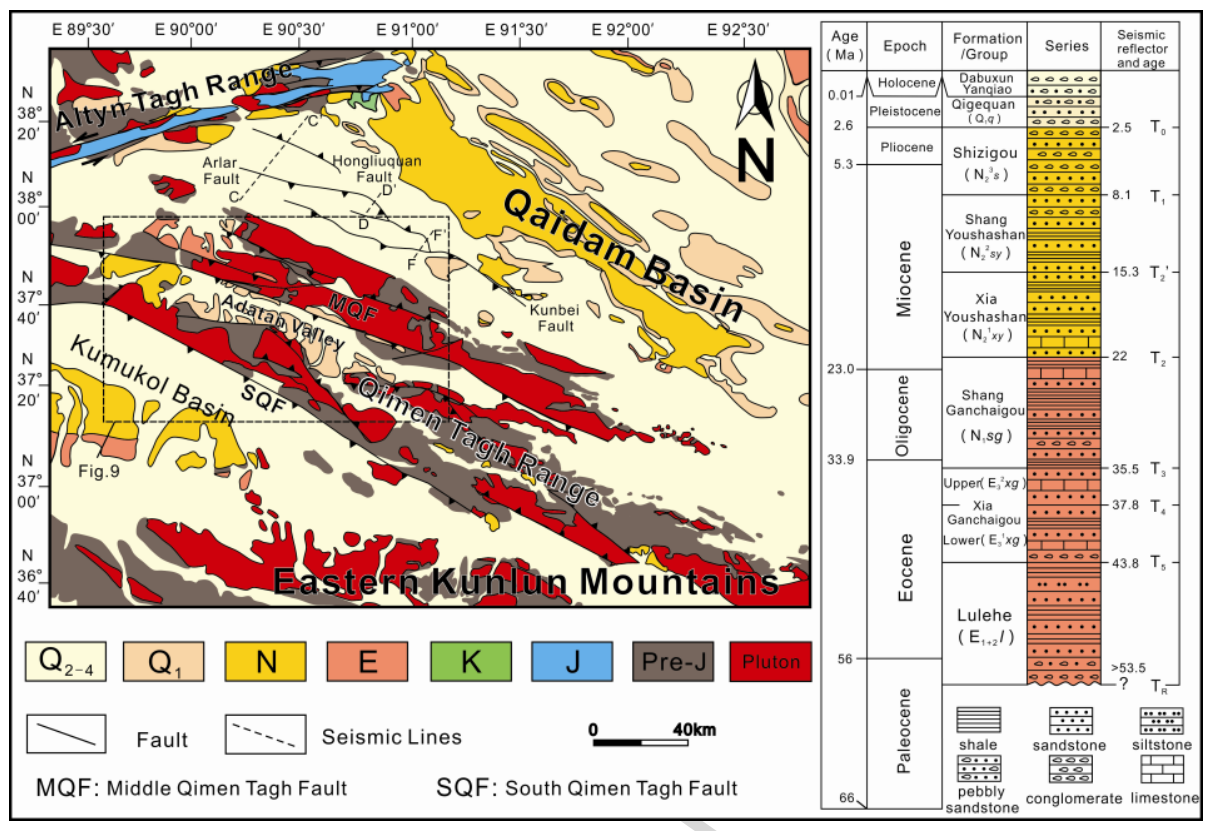

Fig2 


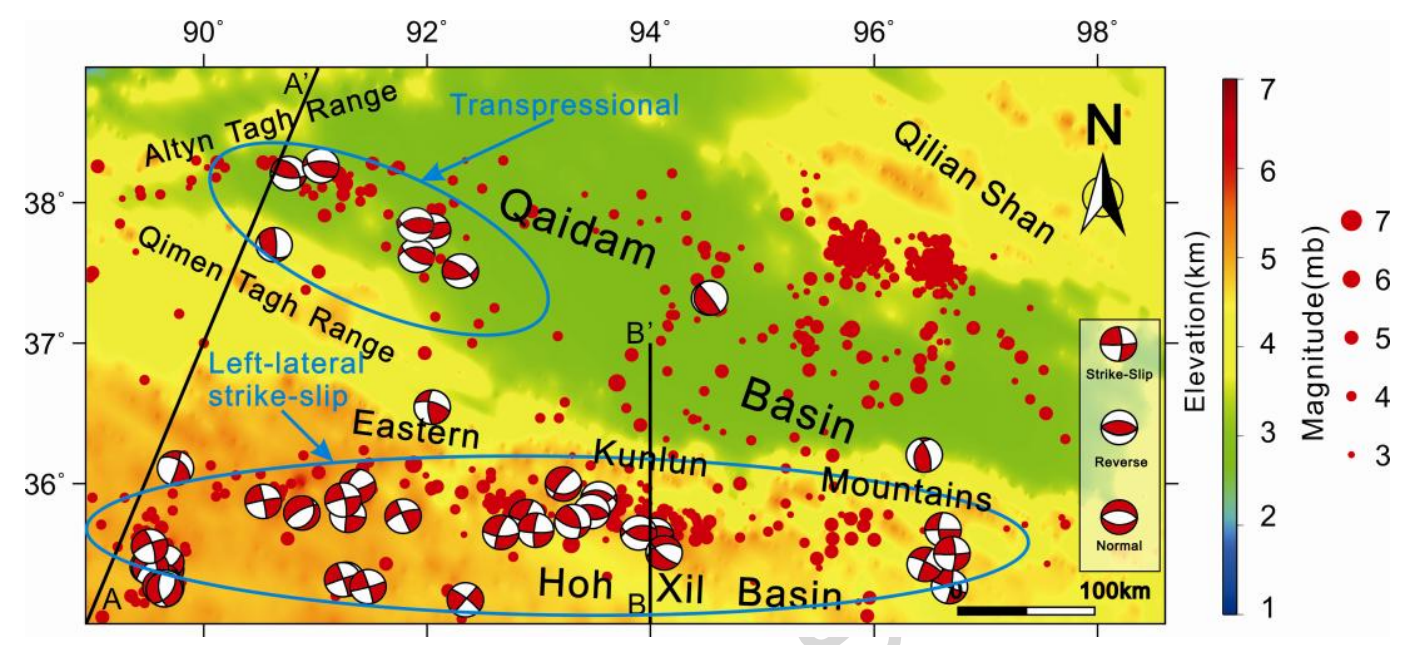

Fig3 


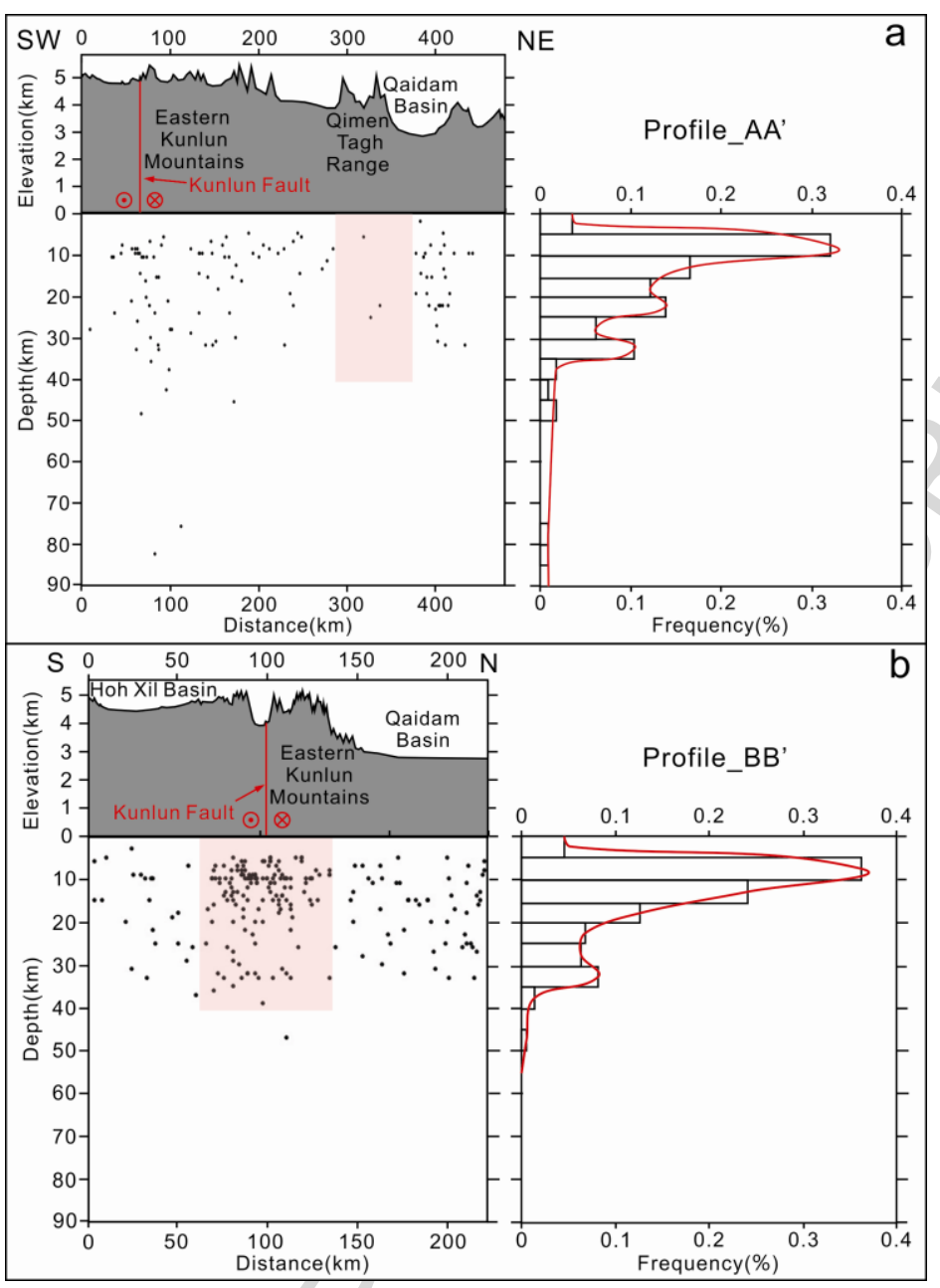

Fig4 


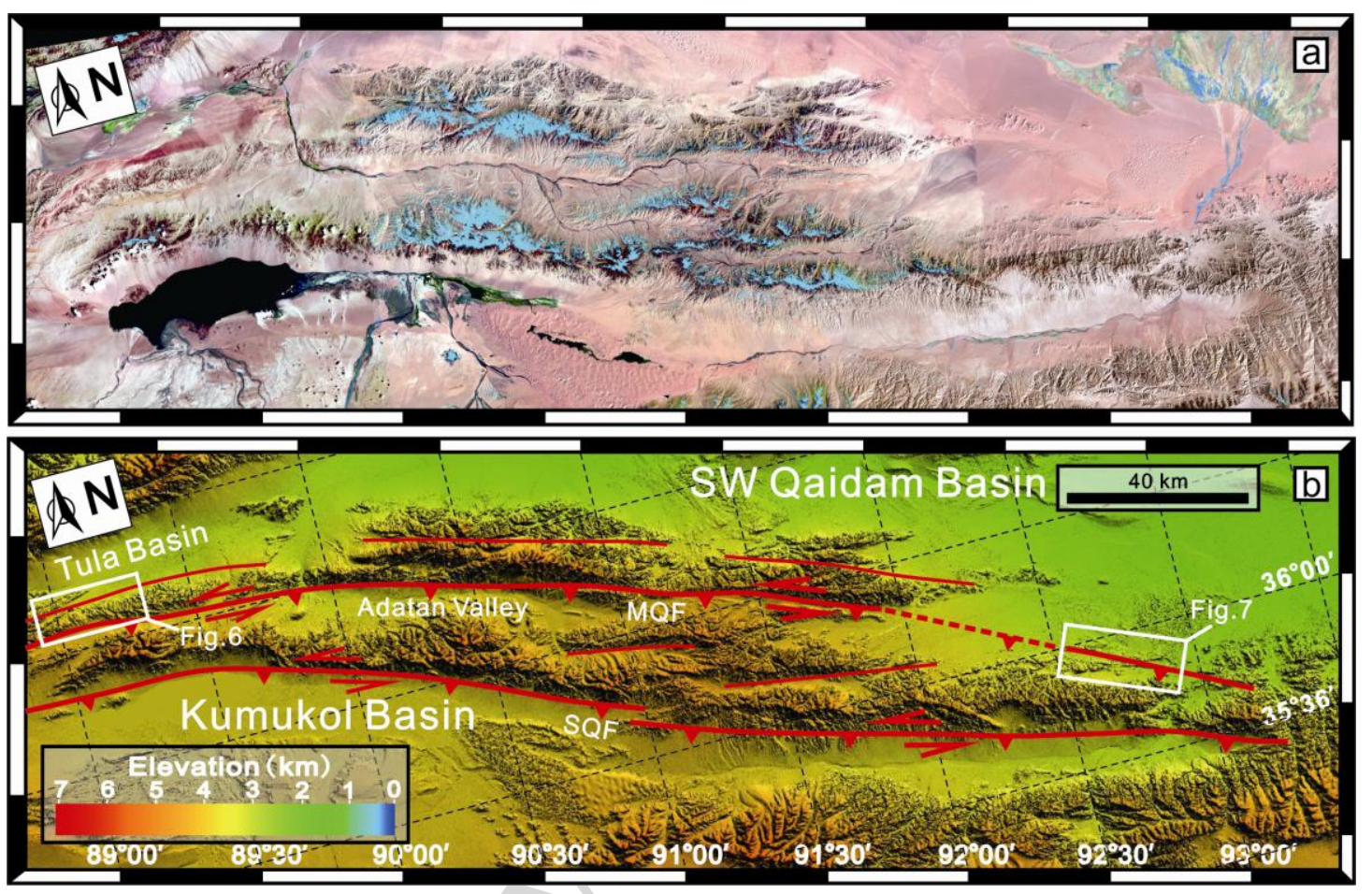

Fig5 


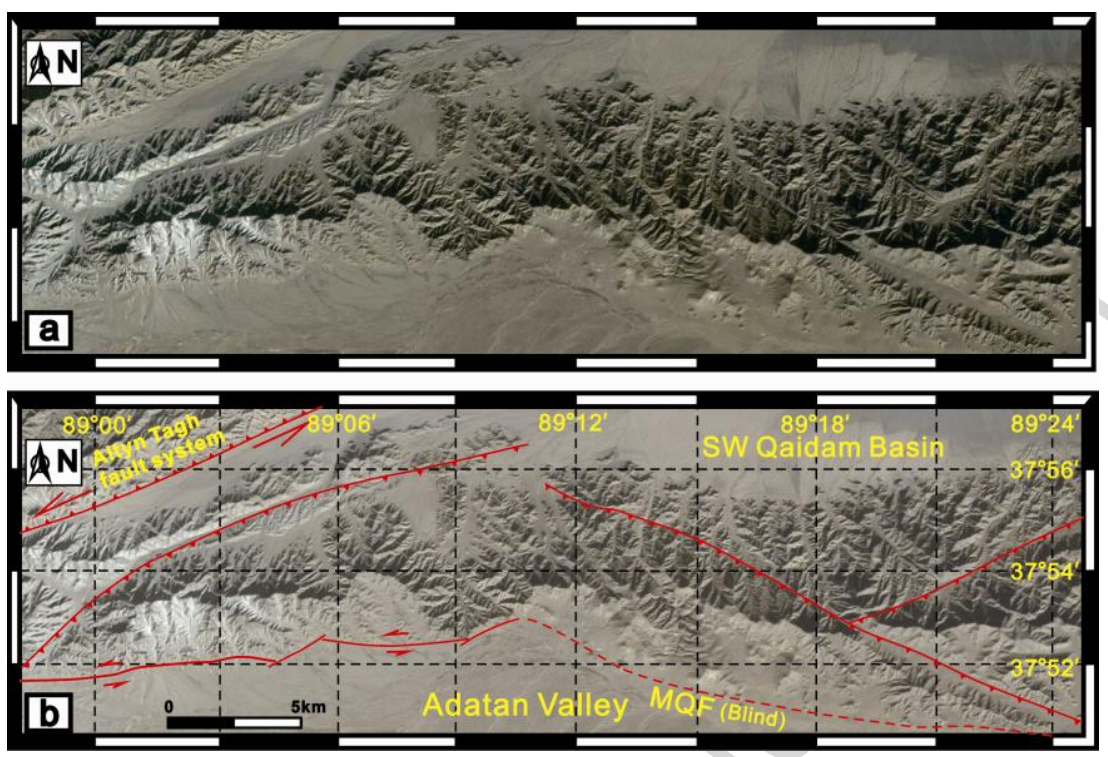

Fig6 

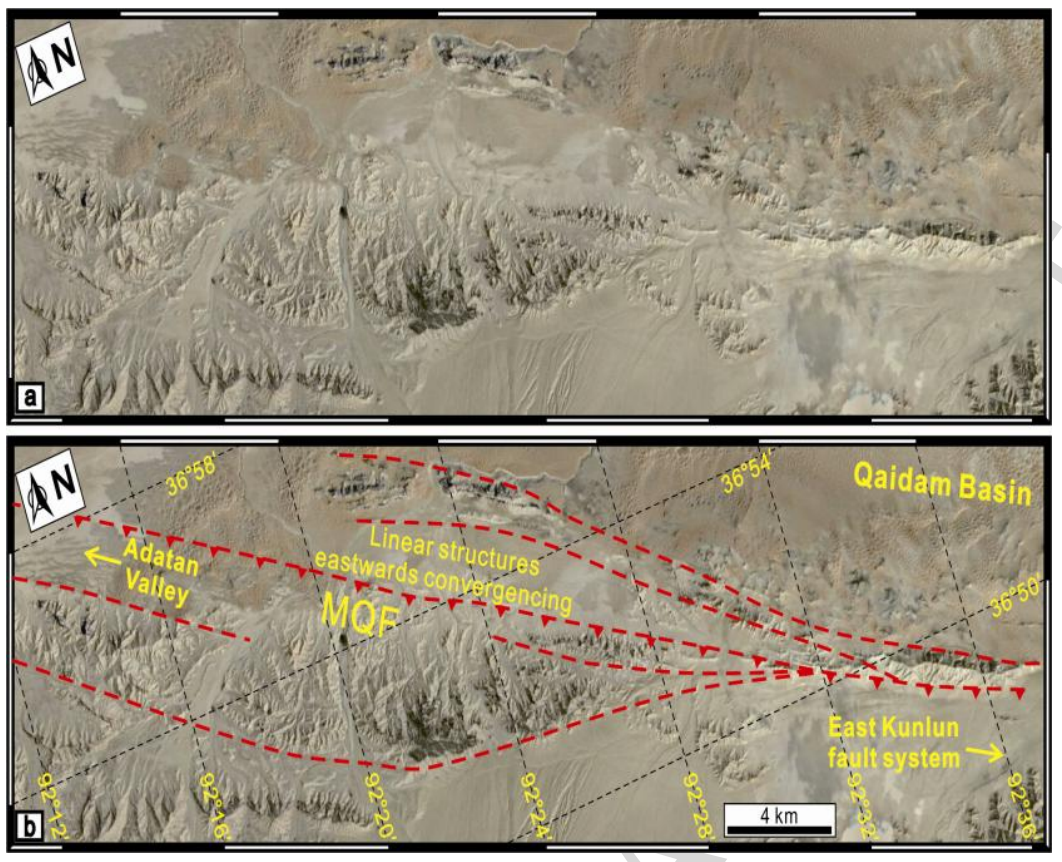

Fig7 


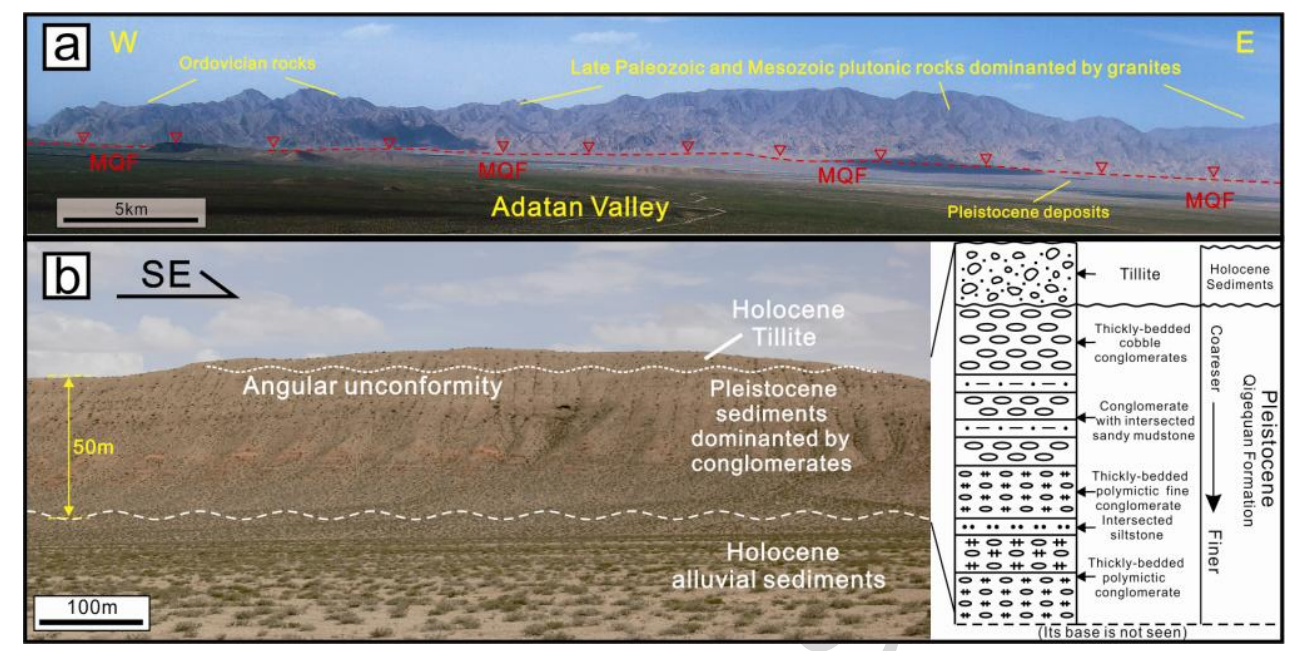

Fig8 


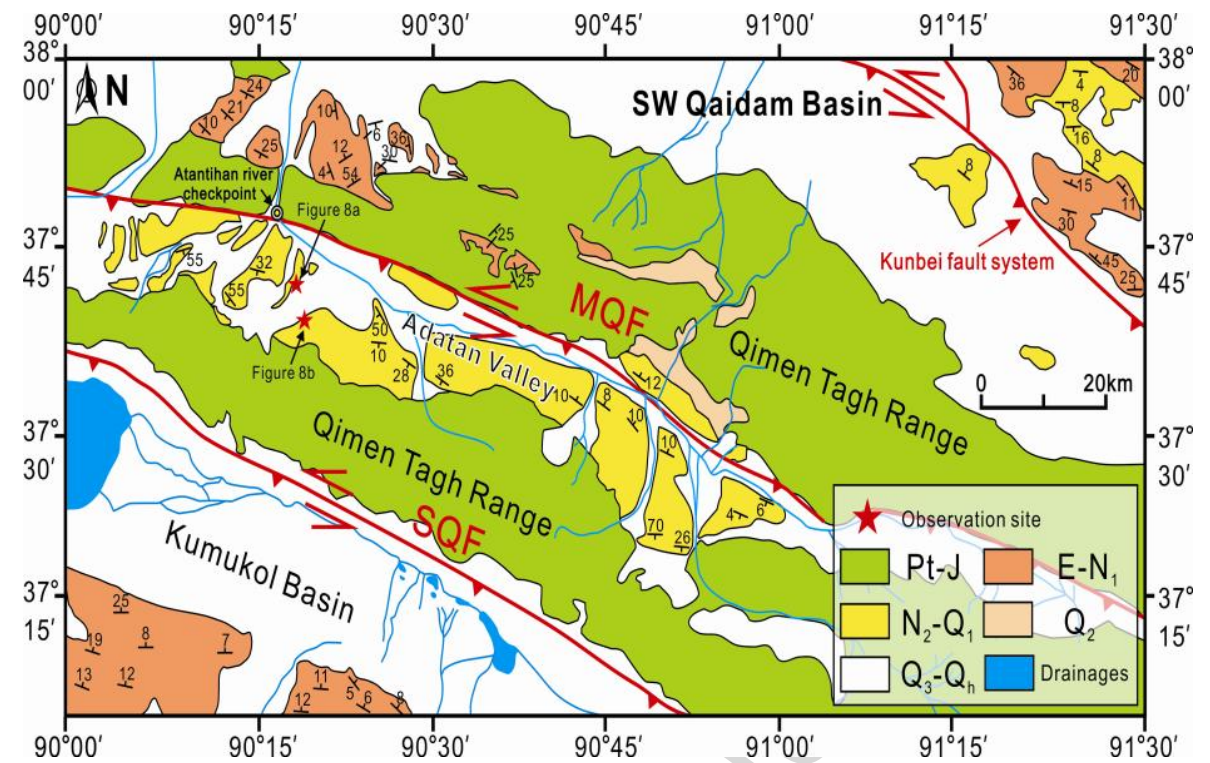

Fig9 


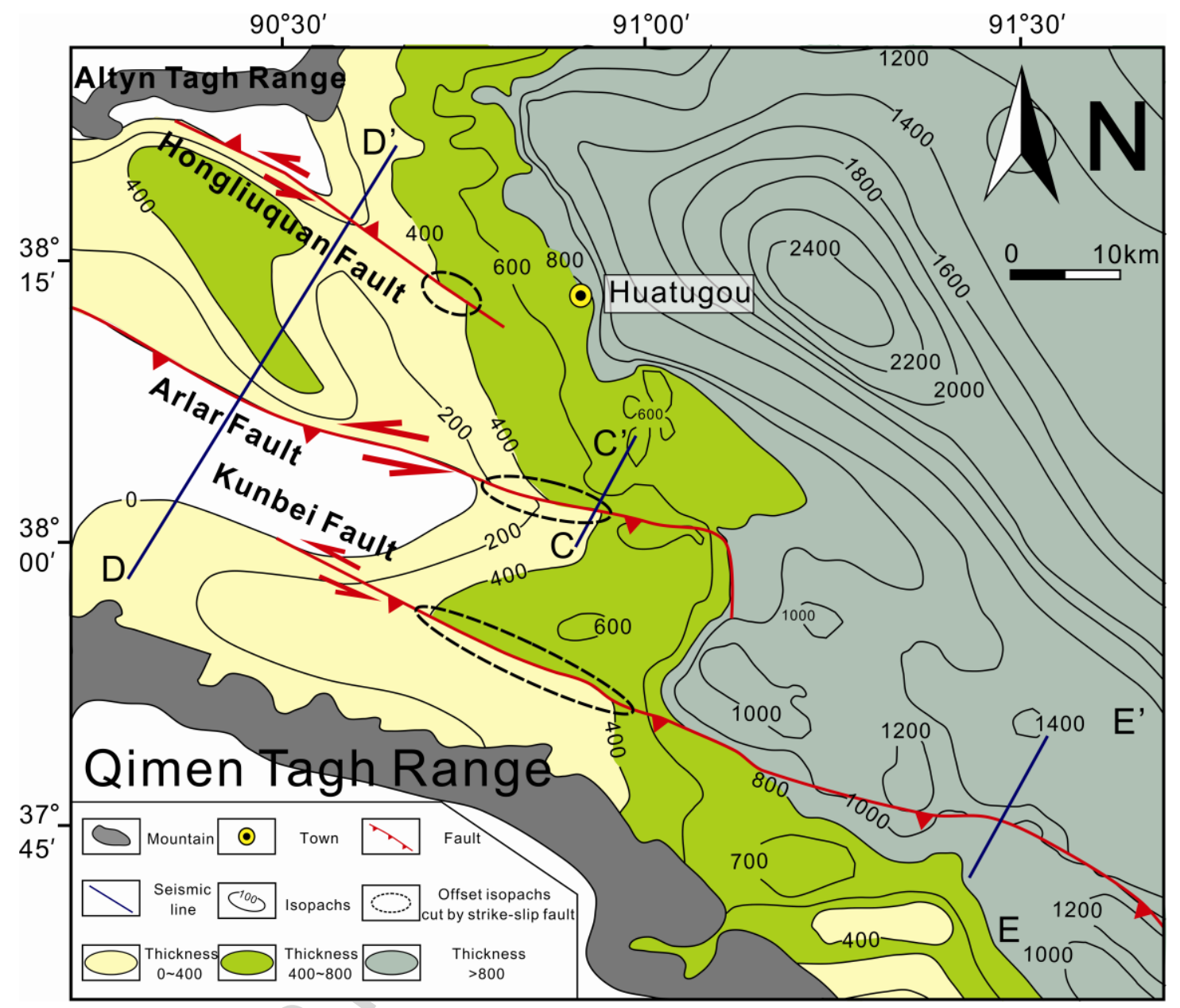

Fig10 

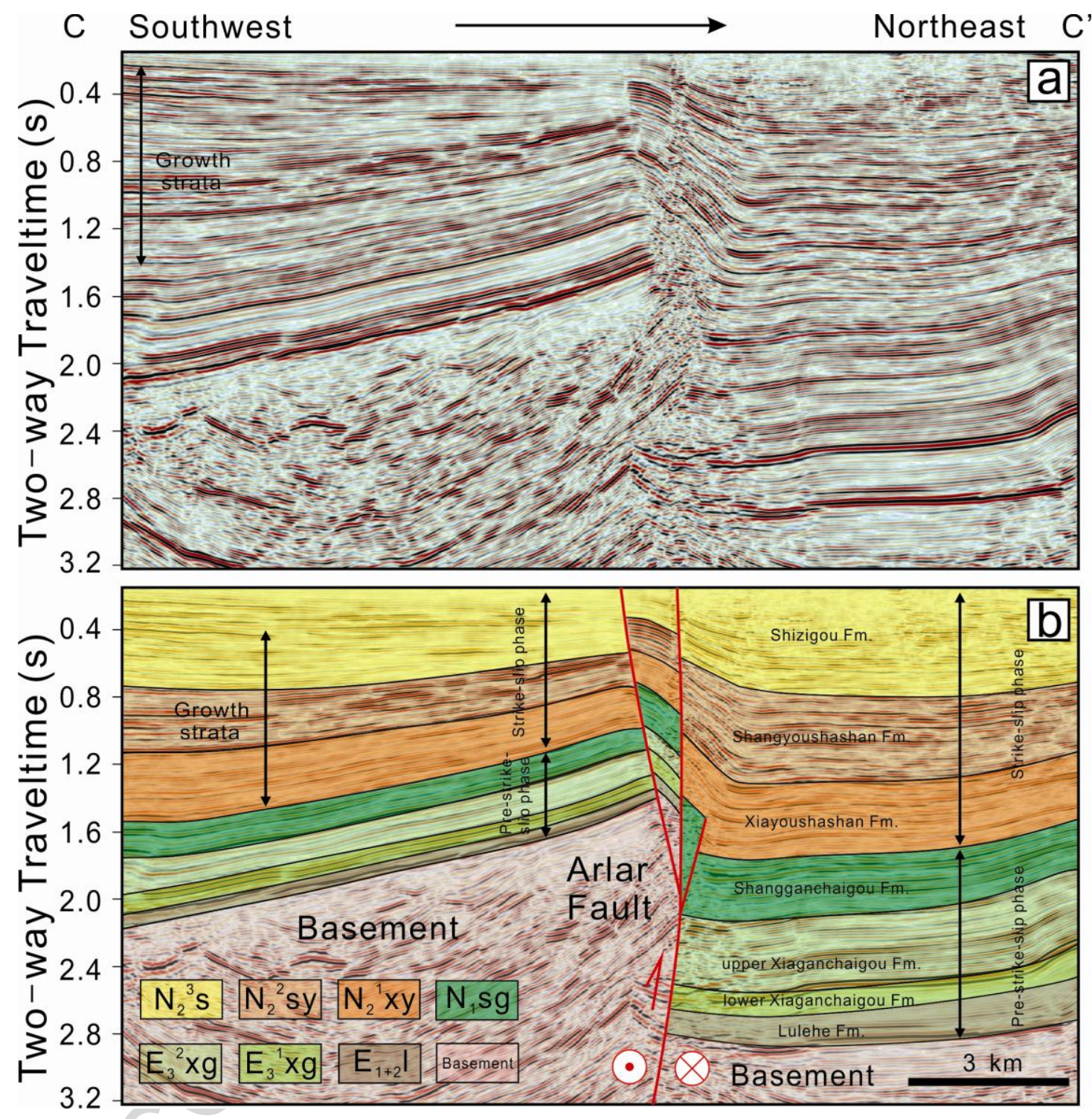

Fig11 


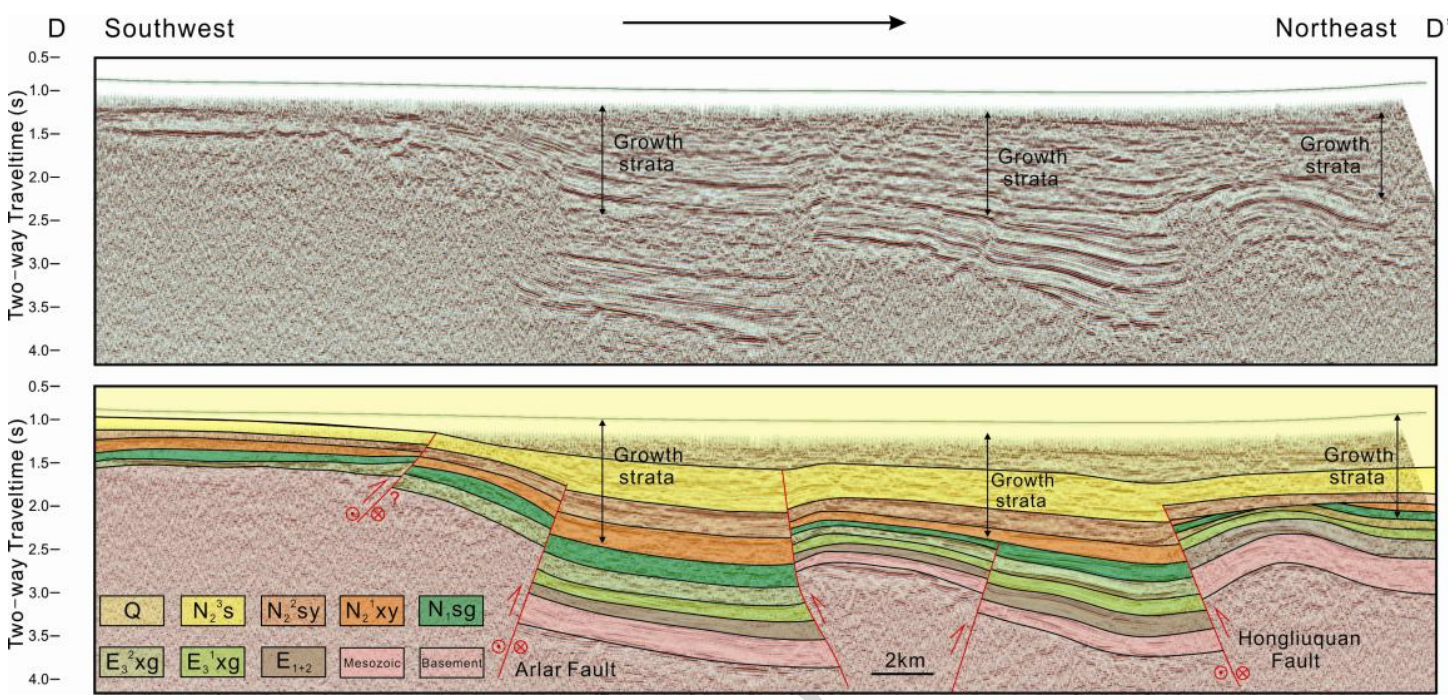

Fig12 

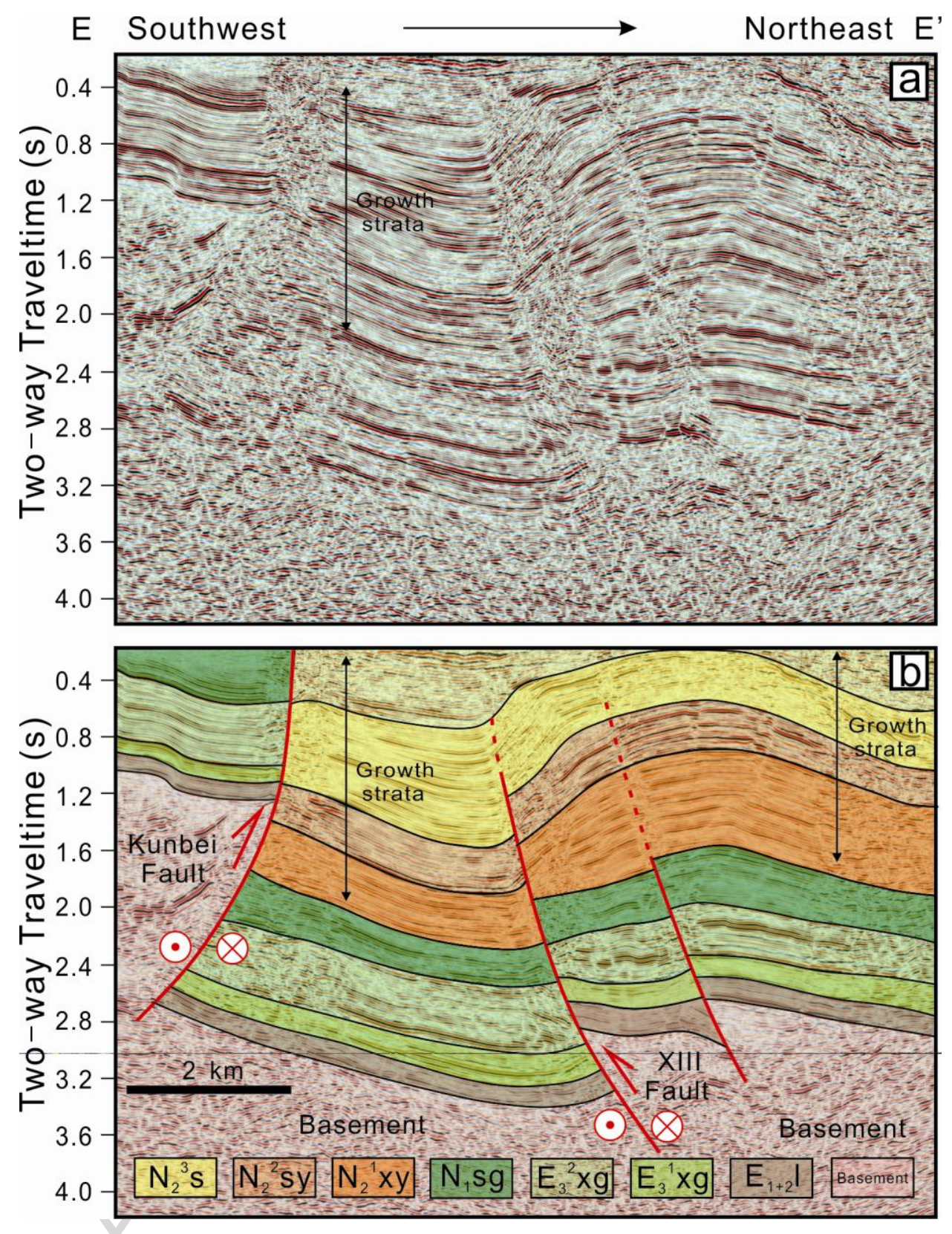

Fig13 


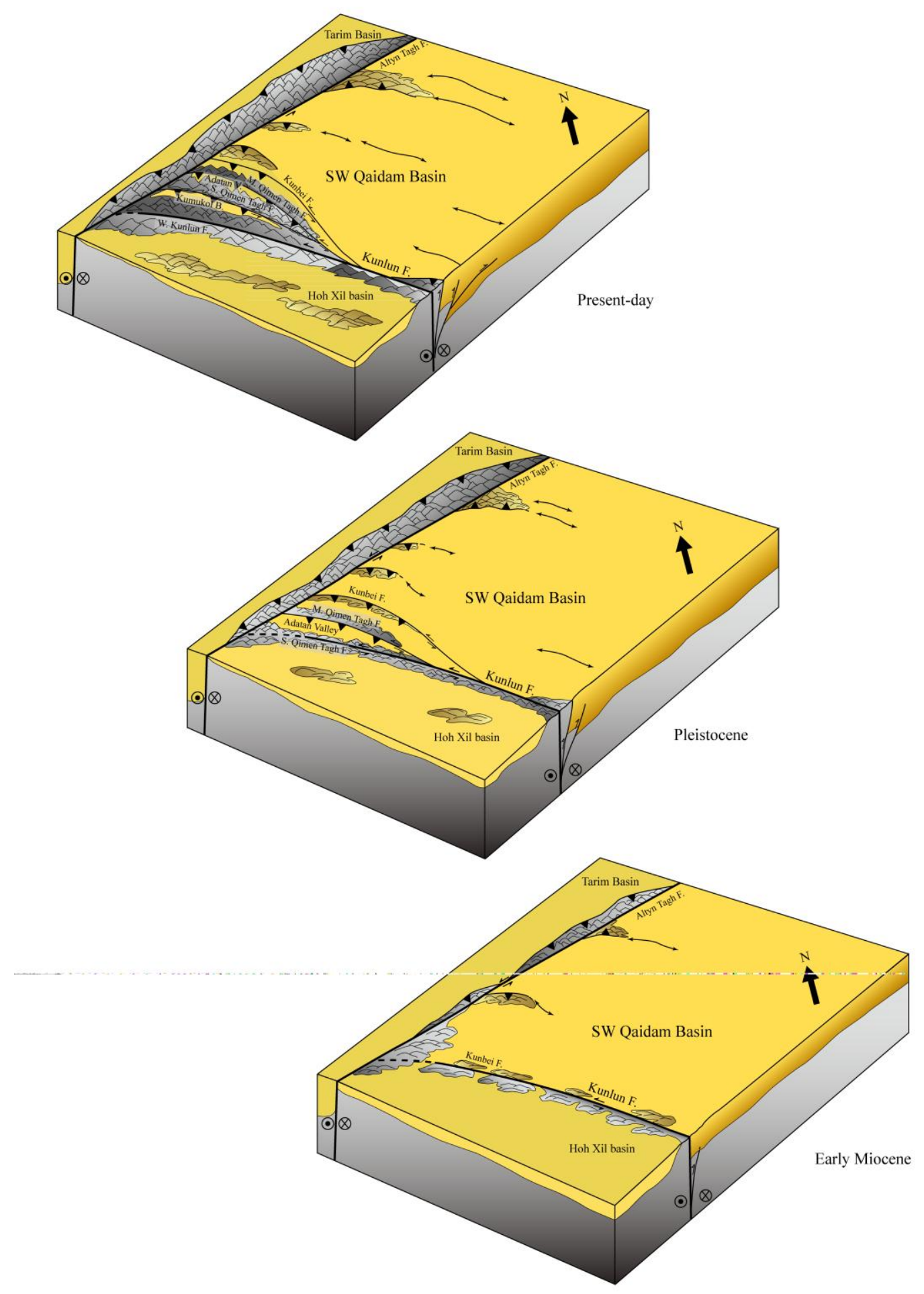

Fig14 


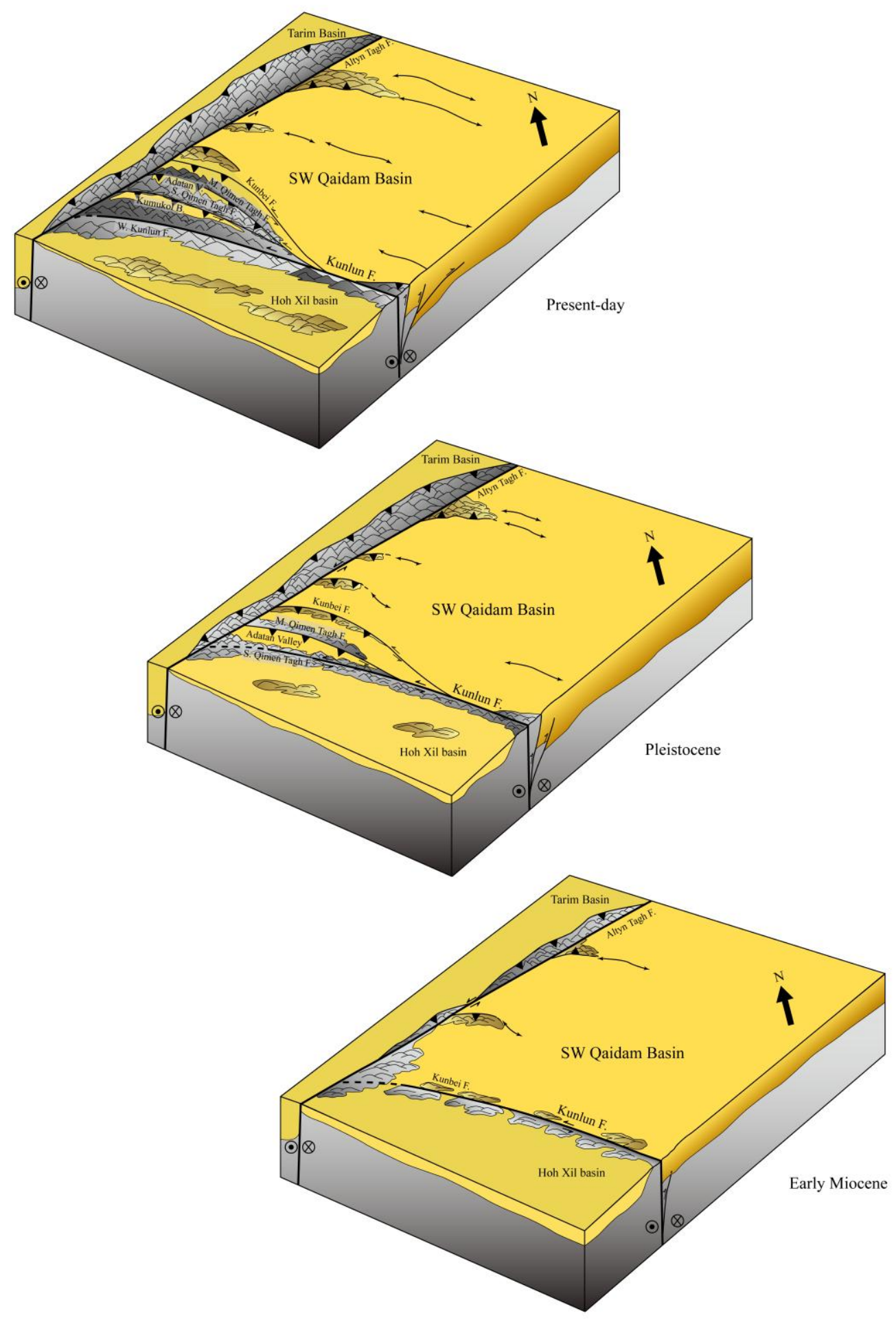

Graphical abstract 


\section{Highlights}

We identify sinistral strike-slip faulting in SW Qaidam Basin and Qimen Tagh Range

Sinstral strike-slip faulting prevailed in SW Qaidam during the Early Miocene

Sinistral strike-slip faulting prevailed in Qimen Tagh Range during the Pleistocene

These strike-slip faults once located further south migrated northwards gradually 